\title{
Multiple Nodulation Genes Are Up-Regulated During Establishment of Reniform Nematode Feeding Sites in Soybean
}

\author{
Nathan W. Redding, Paula Agudelo, and Christina E. Wells ${ }^{\dagger}$
}

Department of Plant and Environmental Sciences, Clemson University, Clemson, SC 29634.

Accepted for publication 13 September 2017.

\begin{abstract}
The semi-endoparastic reniform nematode (Rotylenchulus reniformis) infects over 300 plant species. Females penetrate host roots and induce formation of complex, multinucleate feeding sites called syncytia. While anatomical changes associated with reniform nematode infection are well documented, little is known about their molecular basis. We grew soybean (Glycine max) in a split-root growth system, inoculated half of each root system with $R$. reniformis, and quantified gene expression in infected and control root tissue at four dates after inoculation. Over 6,000 genes were differentially expressed between inoculated and control roots on at least one date (false discovery rate $[\mathrm{FDR}]=0.01,\left|\log _{2} \mathrm{FC}\right| \geq 1$ ), and 507 gene sets

been associated with rhizobia nodulation. These included the noduleinitiating transcription factors CYCLOPS, NSP1, NSP2, and NIN, as well as multiple nodulins associated with the plant-derived peribacteroid membrane. Nodulation-related NIP aquaporins and SWEET sugar transporters were induced, as were plant CLAVATA3/ESR-related (CLE) signaling proteins and cell cycle regulators such as CCS52A and E2F. Nodulins and nodule-associated genes may have ancestral functions in normal root development and mycorrhization that have been co-opted by both parasitic nematodes and rhizobial bacteria to promote feeding site and nodule formation.
\end{abstract} were significantly enriched or depleted in inoculated roots (FDR $=0.05$ ). Numerous genes up-regulated during syncytium formation had previously
Additional keywords: RNA-seq, nodulin, plant-parasitic nematode.
Reniform nematode, Rotylenchulus reniformis (Linford and Oliveira), is a sedentary plant-parasitic nematode with a broad host range. Unlike more host-specific nematode parasites, reniform nematode infects over 300 species from numerous plant families in tropical, subtropical, and warm-temperate regions (Heald and Robinson 1990; Robinson et al. 1997). Among its hosts are multiple economically important crops, including soybean, cotton, and pineapple. Reniform nematode has a significant impact on global crop production and food security; in the United States alone, its infection causes millions of dollars in annual yield losses (Robinson 2007).

Similar to other sedentary plant-parasitic nematodes, reniform nematode induces the formation of permanent feeding structures in host root tissue. Immature females penetrate the epidermis and cortex of a host root, stopping when they reach an endodermal cell. There, each inserts its stylet and releases a proteinaceous secretion that promotes development of a permanent feeding site. Partial cell wall lysis begins at the initial endodermal cell and progresses to multiple cells in the pericycle, ultimately creating a multinucleate syncytium. The amalgamated cells undergo multiple structural and metabolic changes over the course of several days, giving rise to a metabolically active feeding site that nourishes the nematode during her development and reproduction (Rebois 1980; Rebois et al. 1975).

The anatomical changes associated with reniform nematode syncytia have been extensively documented (Agudelo et al. 2005; Jones and Dropkin 1975; Rebois 1980; Rebois et al. 1975), but less is known about their molecular basis, especially in comparison with better-studied parasites like the cyst nematodes (Heterodera and Globodera spp.) and root-knot nematodes (RKN) (Meloidogyne spp.). Cyst nematodes $(\mathrm{CN})$ manipulate host genes to orchestrate partial cell wall lysis in procambium or young vascular tissue,

†Corresponding author: C. E. Wells; E-mail: cewells@clemson.edu

*The $\boldsymbol{e}$-Xtra logo stands for "electronic extra" and indicates that nine supplementary files are published online.

(c) 2018 The American Phytopathological Society inducing the formation of a multinucleate, hypermetabolic syncytium. RKN alter the expression of host genes involved in cell cycle control, cell wall modification, and hormone regulation to induce the formation of "giant cells" in root galls (Cabrera et al. 2015; de Almeida Engler et al. 2015; Wieczorek 2015). Both groups of nematodes suppress defense-related signaling pathways throughout the lifetime of the feeding structure (Jaouannet et al. 2013; Quentin et al. 2013). Whether reniform nematode manipulates host genes in a manner analogous to that of $\mathrm{CN}$ or $\mathrm{RKN}$ is unknown, although recent work suggests that broadly similar groups of genes may be involved (Li et al. 2015).

Previous work has highlighted overlap in physiology and gene expression between rhizobia root nodules and CN/RKN feeding sites. RKN giant cells in Medicago truncatula exhibit altered expression of the nodule-associated transcriptional regulators PHAN and KNOX, the early nodulin ENOD40, the cell cycle regulator CCS52a, and the cytokinin primary-response gene ARR5 (Lohar et al. 2004). Hypernodulated (harl) Lotus japonicus mutants exhibit both increased nodulation and increased RKN infection (Lohar and Bird 2003). Similarly, the production of rhizobia-signaling isoflavonoids is upregulated during $\mathrm{CN}$ infection, and a beet $\mathrm{CN}$ resistance gene is highly expressed during both $\mathrm{CN}$ and rhizobia infection (Kennedy et al. 1999; Mitra et al. 2004).

Mounting evidence supports the hypothesis that diverse belowground symbionts and parasites have evolved to manipulate a similar genetic toolkit in their hosts. Genes normally involved in lateral root development and substrate transport are co-opted to support the formation of root nodules, mycorrhizae, and feeding sites (Lohar and Bird 2003; Lohar et al. 2004; Mathesius 2003; Wasson et al. 2009). In the context of nodulation, these genes have been termed nodulins. They include many sugar, nutrient, amino acid, and hormone transport proteins, as well as transcription factors, phosphatidylinositol transfer family proteins, and cell cycle regulators (Denance et al. 2014; Desbrosses and Stougaard 2011; Ferguson et al. 2010; Ghosh et al. 2015; Maroti and Kondorosi 2014; Verma et al. 1986). While most extensively studied in the context of nodulation, nodulins and nodule-associated genes are also present in the genomes of nonleguminous plants and are 

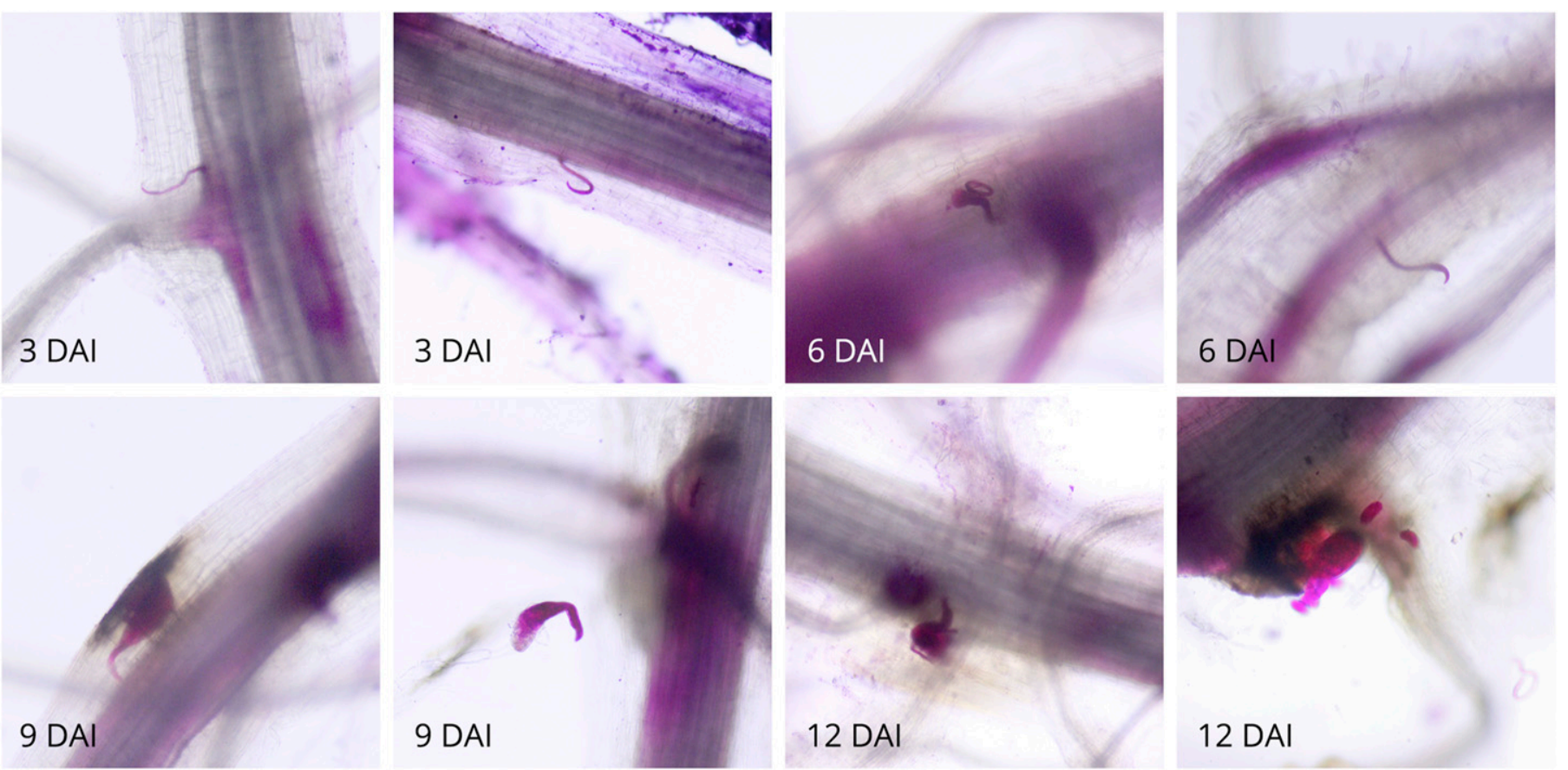

Fig. 1. Micrographs of acid fuchsin-stained soybean roots and reniform nematodes taken at 100x magnification at 3, 6, 9, and 12 days after inoculation (DAI).

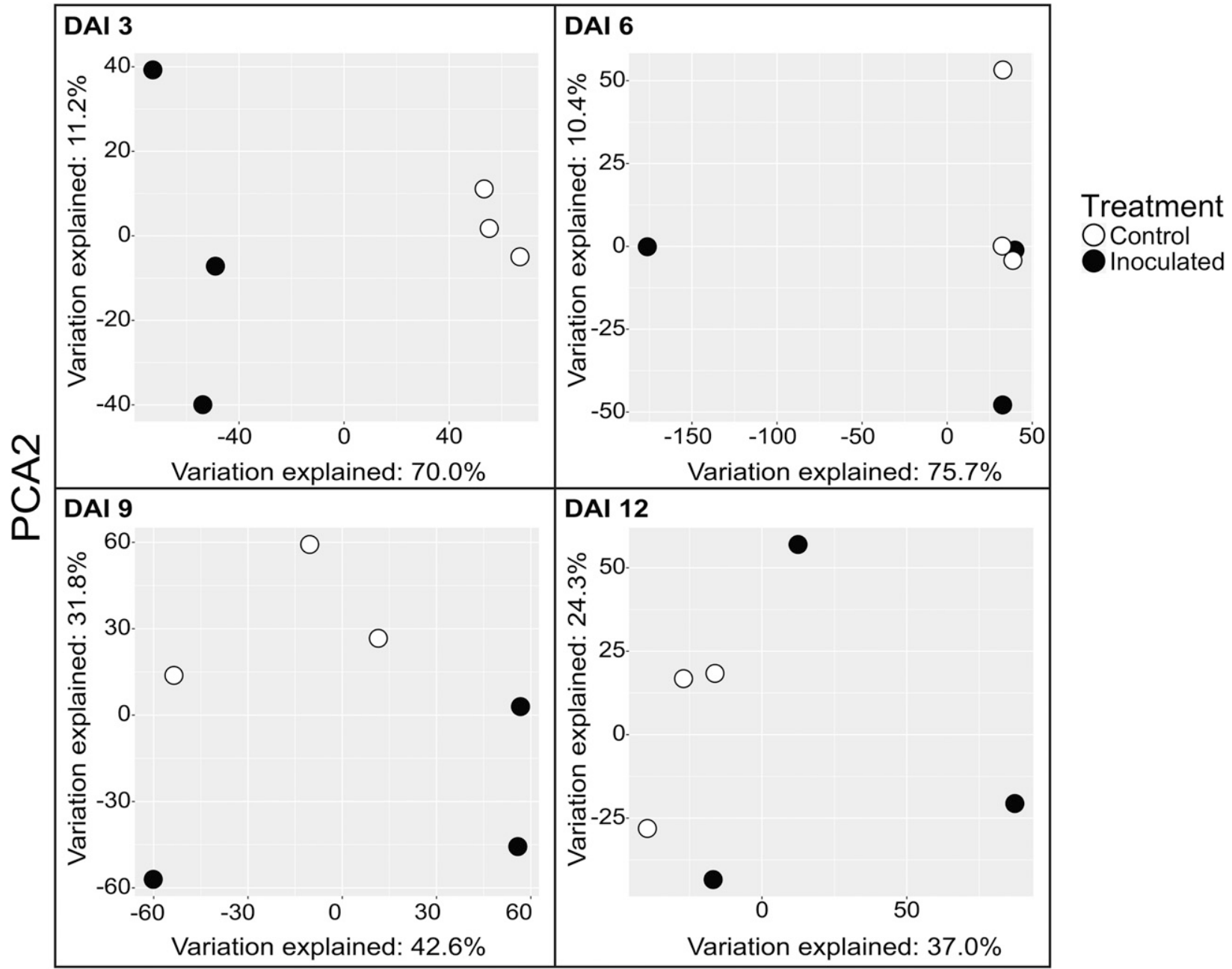

PCA1

Fig. 2. Visualization of gene expression data using principal components analysis of rlog-transformed counts for all genes in control and inoculated soybean roots at four time points after inoculation. 
expressed in nonnodulation contexts (Denance et al. 2014; Reddy et al. 1999; Vieira-de-Mello et al. 2011).

Here we report the reference-guided assembly of a soybean (Glycine max) transcriptome from control and reniform nematode infected roots over a 12-day time course. We describe a split-root growth system that allows us to harvest infected and noninfected control roots from the same plant. We identify individual genes and gene sets whose expression is altered in reniform nematodeinfected roots, and we report the up-regulation of multiple wellknown nodulins and nodule-associated genes during reniform nematode parasitism of soybean.

\section{MATERIALS AND METHODS}

Split-root growth system and nematode inoculation. To minimize the effects of plant-to-plant variation on identification of genes related to reniform nematode infection, we developed a splitroot growth system that permitted the collection of infected and control root tissue from the same plant. Surface-sterilized seeds of the reniform nematode-susceptible Glycine max 'Hutcheson' were germinated on sterilized vermiculite and maintained in a growth room at $28 \pm 2{ }^{\circ} \mathrm{C}$ and $50 \%$ relative humidity (RH) with a $14-\mathrm{h} / 10$-h (light/ dark) photoperiod. The soybean seed had been grown and collected in our greenhouses and was not coated with the rhizobial inoculum commonly present on commercial seed. After cotyledon emergence, a horizontal cut was made at the base of each primary root to encourage lateral root proliferation. After 1 week, the lateral roots were grouped into two equal bundles, threaded through the arms of a Y-shaped plastic tube (diameter $2.22 \mathrm{~cm}$ ), and directed into adjacent $300 \mathrm{~cm}^{3}$ pots filled with pasteurized fine sand. Plants were grown for 1 week, and 12 uniform plants were then selected for use in the experiment.

Reniform nematode inoculum was prepared from soil collected in a St. Matthews, SC agricultural field that had been under cotton and corn rotation for many years. Nematodes were extracted by sugar centrifugal flotation, rinsed, and collected in a $500 \mu \mathrm{m}$ mesh sieve (Jenkins 1964). Following inspection and quantification, nematodes were suspended in tap water at a concentration of 1,500 individuals $/ \mathrm{ml}$. One pot in each split-root system was selected at random and inoculated with $2 \mathrm{ml}$ of the nematode suspension $(3,000$ individuals); the other pot received an equivalent volume of tap water as a negative control.

Three replicate plants were harvested at 3, 6, 9, and 12 days after inoculation (DAI) for microscopy and RNA extraction as described below. Thorough examination of scanned root images on each harvest date confirmed that no nodules were present on any root samples. Additional inoculated and noninoculated plants that were grown for 18 days in the same pasteurized sand system also showed no evidence of nodulation.

Microscopy. Inoculated root samples were obtained from three replicate plants on each harvest date. Roots were gently rinsed free of soil, cleared with chloride bleach, and stained with acid fuchsin following the protocol of Bybd et al. (1983). Briefly, cleaned root

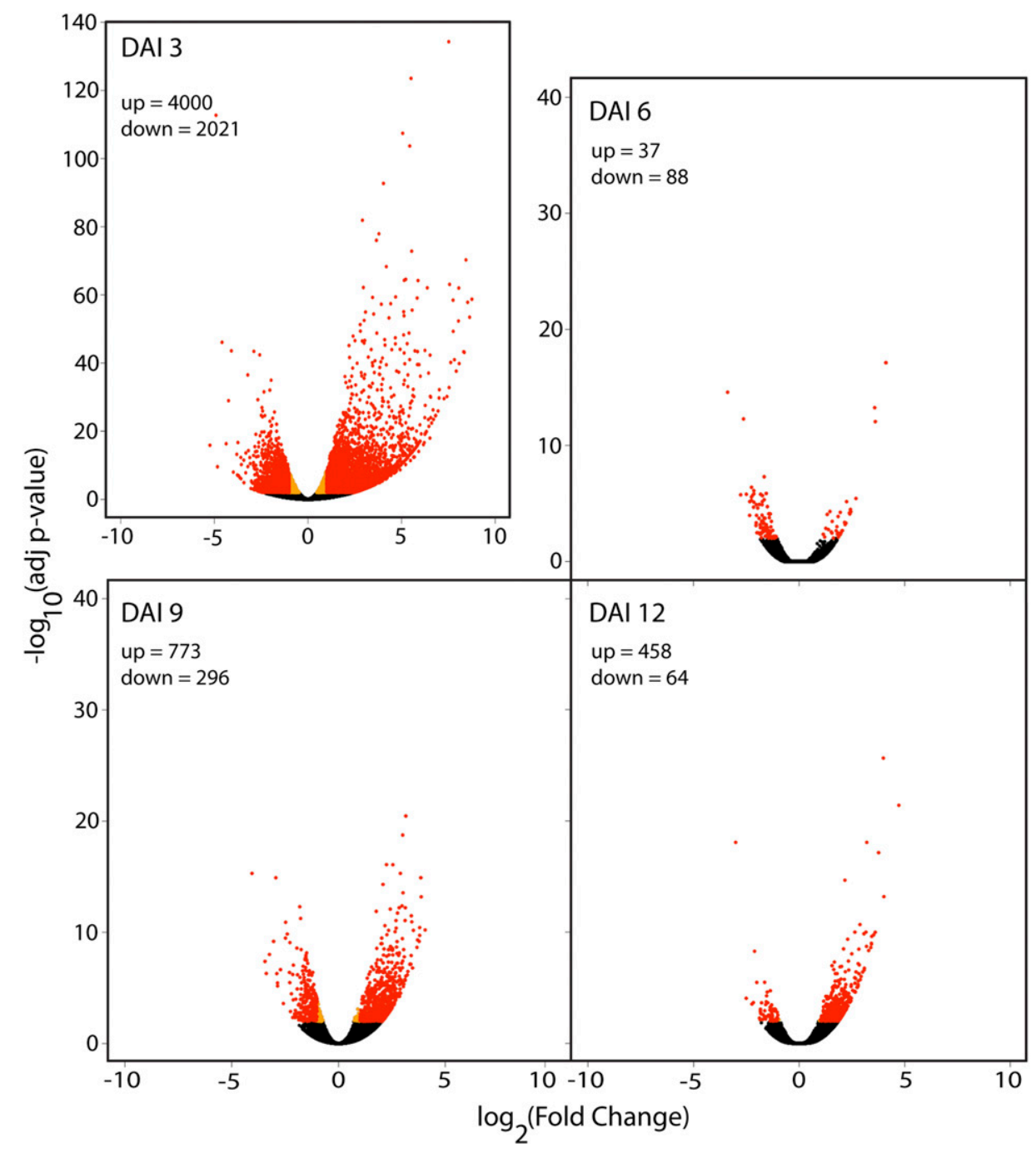

Fig. 3. Volcano plots of false discovery rate (FDR) adjusted $P$ values graphed against $\log _{2}$ (fold change) estimates for all expressed genes at four time points after inoculation. Black symbols: $\mathrm{p}$-adj $>0.01$; yellow symbols: $\mathrm{p}$-adj $\leq 0.01$ and $\left|\log _{2} \mathrm{FC}\right|<1$; red symbols: $\mathrm{p}$-adj $\leq 0.01$ and $\left|\log _{2} \mathrm{FC}\right| \geq 1$. Numbers in the top left of each panel reflect numbers of significantly up- and down-regulated genes in infected roots on each date. 
samples were incubated in $0.9 \% \mathrm{NaOCl}$ for $4 \mathrm{~min}$, rinsed, and placed in tap water for $15 \mathrm{~min}$ to remove residual bleach. After a second rinse, roots were heated to boiling in beakers with $30 \mathrm{ml}$ of tap water and $1 \mathrm{ml}$ of acid fuchsin stain $(3.5 \mathrm{~g}$ of acid fuchsin, $250 \mathrm{ml}$ of acetic acid, and $750 \mathrm{ml}$ of water). After boiling for $30 \mathrm{~s}$, the beakers were cooled to room temperature, and the roots were rinsed in tap water, placed in acidified glycerol, and heated until destained. Once cooled, roots and stained nematodes were photographed on an inverted microscope at 100× magnification (Motic AE2000 with Cannon EOS Rebel T3i Camera). Neither nodules nor nodule primordia were observed in any root sample.

Transcriptome sequencing. Approximately $500 \mathrm{mg}$ fresh weight (FW) of infected and control root tissue was harvested from each of three replicate plants at 3, 6, 9, and 12 days after reniform nematode inoculation, for a total of 24 samples (two infection statuses $\times$ four dates $\times$ three biological replicates). Tissue was stored in RNAlater Stabilization Reagent (Ambion, Austin, TX) and sent to the University of Arizona Genetics Core (Tucson, AZ). RNA was extracted using the Qiagen RNAeasy Mini Kit, and RNA quality was assessed with the Agilent 2100 Bioanalyzer prior to 100-bp paired-end library preparation with the Illumina TruSeq 2 RNA kit. Samples were sequenced across two lanes of the Illumina HiSeq 2000 platform (Illumina, San Diego, CA).

A total of 309.5 million paired-end 100-bp reads were generated across the experiment, with an average of 12.8 million reads per sample. Read quality was assessed with FastQC v0.10.1, sequencing adaptors were trimmed with Trimmomatic v0.32 (Bolger et al. 2014), and low-quality bases were removed using the default settings of ConDeTri v2.2 (Smeds and Kunstner 2011). The average per-read PHRED quality score after trimming was 36.7 , and the minimum per-read score was 36.02. All raw reads were uploaded to the NCBI Sequence Read Archive under accession number SRP091708.

Transcriptome assembly and annotation. Trimmed reads from each sample were mapped to the Wm82.a1.v1 build of the

TABLE 1. Top 20 genes whose expression was significantly up-regulated in reniform nematode-infected soybean roots at four time points after inoculation (false discovery rate $=0.01$, genes ranked based on $\log _{2} \mathrm{FC}$ estimate) ${ }^{\mathrm{a}}$

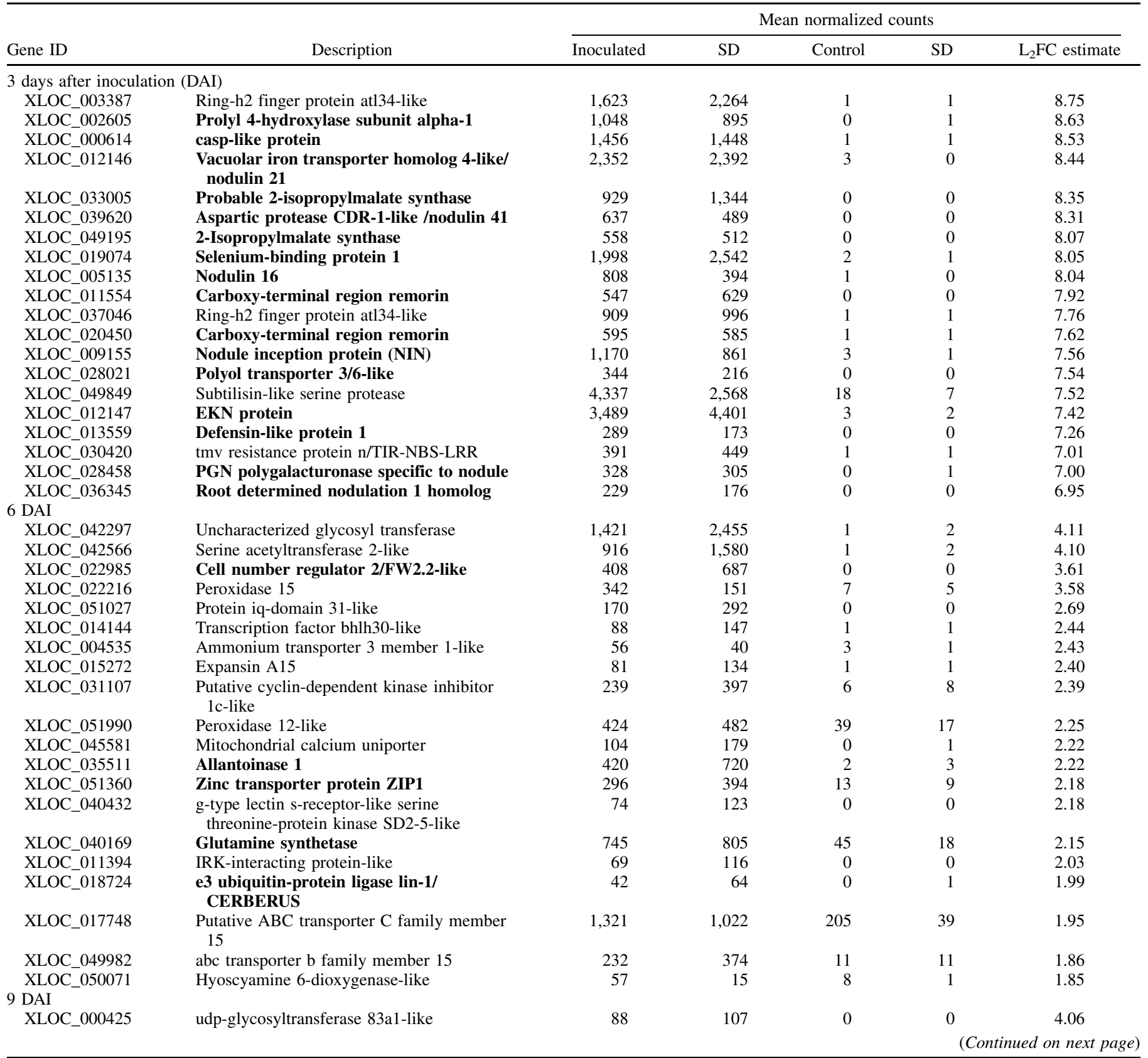

a Bolded genes have previously been identified as nodulins or as playing a role in legume-rhizobia nodulation. 
soybean reference genome using Bowtie2 v2.1.0 and TopHat v2.0.11 with default parameters (Trapnell et al. 2012). The -G option was used to supply TopHat with the Glyma1.0 reference gene models as a GTF file (Schmutz et al. 2010). Transcripts were assembled separately for each sample using Cufflinks v2.2.1, then merged with the Glyma1.0 reference annotation to generate a soybean root transcriptome that included both previously described and newly assembled transcripts (Trapnell et al. 2012). The new reference transcriptome was annotated in Blast2GO Pro v3.0, which performs a BLASTx search against the NCBI nr protein database and assigns sequence descriptions, gene ontology (GO) terms, Interpro IDs, enzyme codes (EC), and KEGG pathways to transcripts with significant blast hits $\left(\mathrm{E}<10^{-6}\right)$ (Conesa et al. 2005).

Gene expression was quantified by mapping reads from individual samples back to the new transcriptome using HTSeq v0.6.1 (Anders et al. 2015). Reads from all splice forms of a given gene were pooled, and count data were imported to DESeq2 for differential expression analysis using default parameters (Love et al. 2014). Data were analyzed separately by date to identify genes differentially expressed between inoculated and noninoculated roots, while controlling for the effect of individual plants (false discovery rate $[\mathrm{FDR}]=0.01)$. Genes were considered to be significantly differentially expressed when they fulfilled two criteria: (i) an FDR-adjusted $P$ value of $\leq 0.01$ and (ii) a $\mid \log _{2}$ (fold change) estimate of $\geq 1$. The $\log _{2} \mathrm{FC}$ estimates were calculated in DESeq 2 and implemented empirical Bayes shrinkage to permit accurate comparison of effect sizes across all genes (Love et al. 2014).

In parallel with the identification of individual DE genes, gene set enrichment analysis (GSEA) was performed to identify predefined gene sets whose expression was significantly enriched or depleted in inoculated roots (Subramanian et al. 2005). A custom GSEA database of 1,499 predefined gene sets, each containing at least 15 genes, was created from GO terms, enzyme codes, and KEGG pathway annotations of the root transcriptome. Gene sets whose expression was enriched or depleted in inoculated roots on each date were identified using an FDR of 0.05 .

To assess the possibility of rhizobial contamination, raw reads from individual soybean root samples were mapped to the sequenced genomes of rhizobial bacteria and other prokaryotic and eukaryotic model organisms. The reference genomes of eight nodulating bacterial species (Bradyrhizobium diazoefficiens, B. elkanii, B. japonicum, Mesorhizobium loti, Rhizobium etli, R. leguminosarum, Sinorhizobium

TABLE 1. (Continued from previous page)

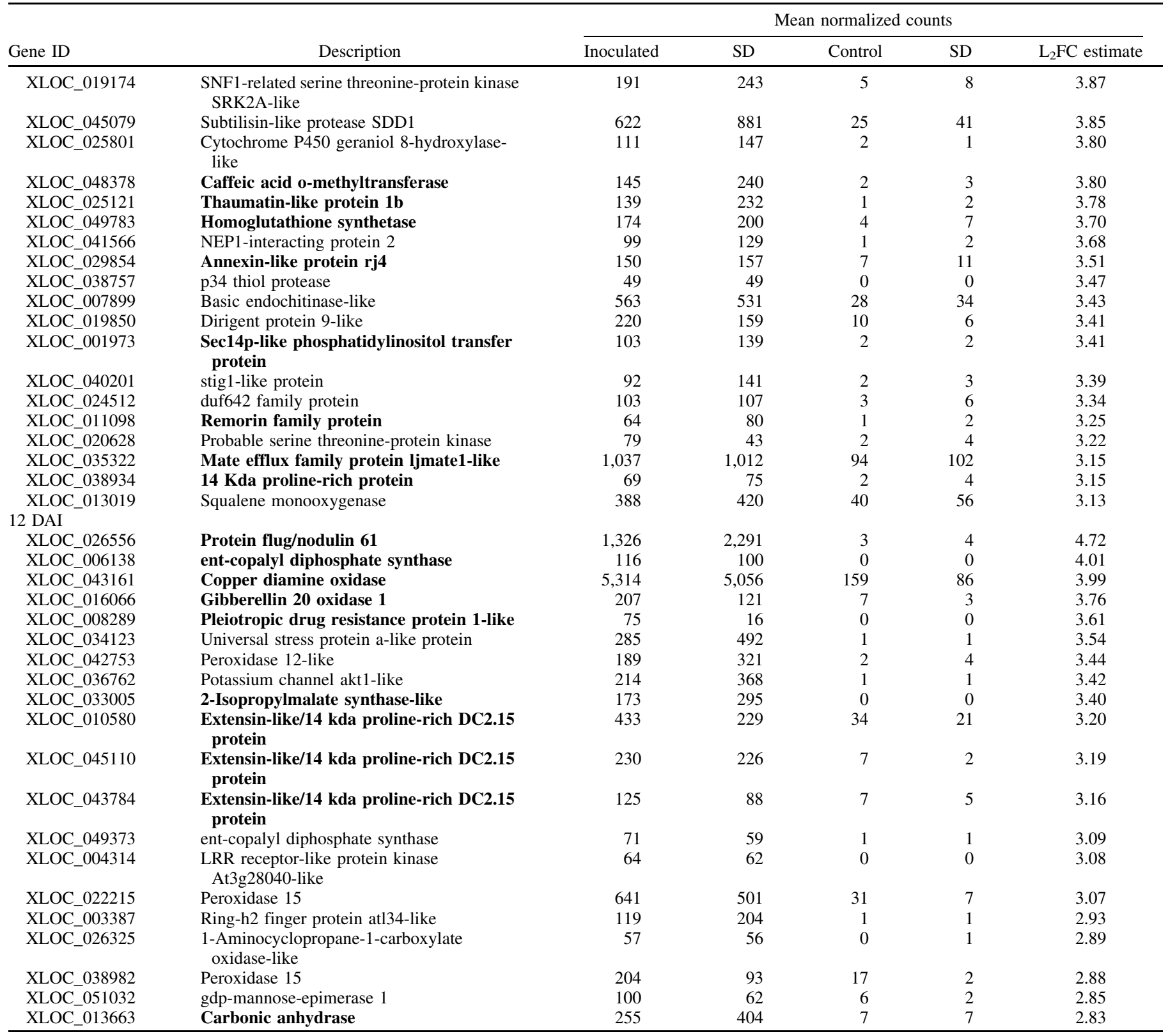


fredii, and S. meliloti) and six additional model organisms (Escherichia coli, Saccharomyces cerevisiae, Drosophila melanogaster, Xenopus laevis, and Danio rerio) were obtained from NCBI. Trimmed reads from each soybean root sample were mapped to each reference genome using Bowtie2 v2.1.0 with default parameters (Langmead and Salzberg 2012). The percentage of reads from each sample that mapped to each genome was calculated with HTSeq v0.6.1. Two-way ANOVAs were used to test for differences in percent mapped reads between inoculated and control samples for each genome and date.

The percent reads that could be successfully aligned to these nonplant genomes was extremely low, never exceeding 2.06E-05 percent for any sample. Across all dates and genomes, there were no significant differences in the percent mapped reads between inoculated and control samples. The percent reads that could be aligned to nodulating bacterial genomes (range: 0 to $2.06 \mathrm{E}-05$ ) were similar in magnitude to the percent that could be aligned to E. coli, animal, and fungal genomes (range: 0 to $2.01 \mathrm{E}-05$ ). It is likely that these reads derive from genes and gene segments that are highly conserved across species.

\section{RESULTS}

Microscopy. Histology of infected roots documented the progress of reniform nematode infection through time and provided context for the gene expression results (Fig. 1). At 3 DAI, all

TABLE 2. Top 20 genes whose expression was significantly down-regulated in reniform nematode-infected soybean roots at four time points after inoculation (false discovery rate $=0.01$, genes ranked based on $\log _{2} \mathrm{FC}$ estimate)

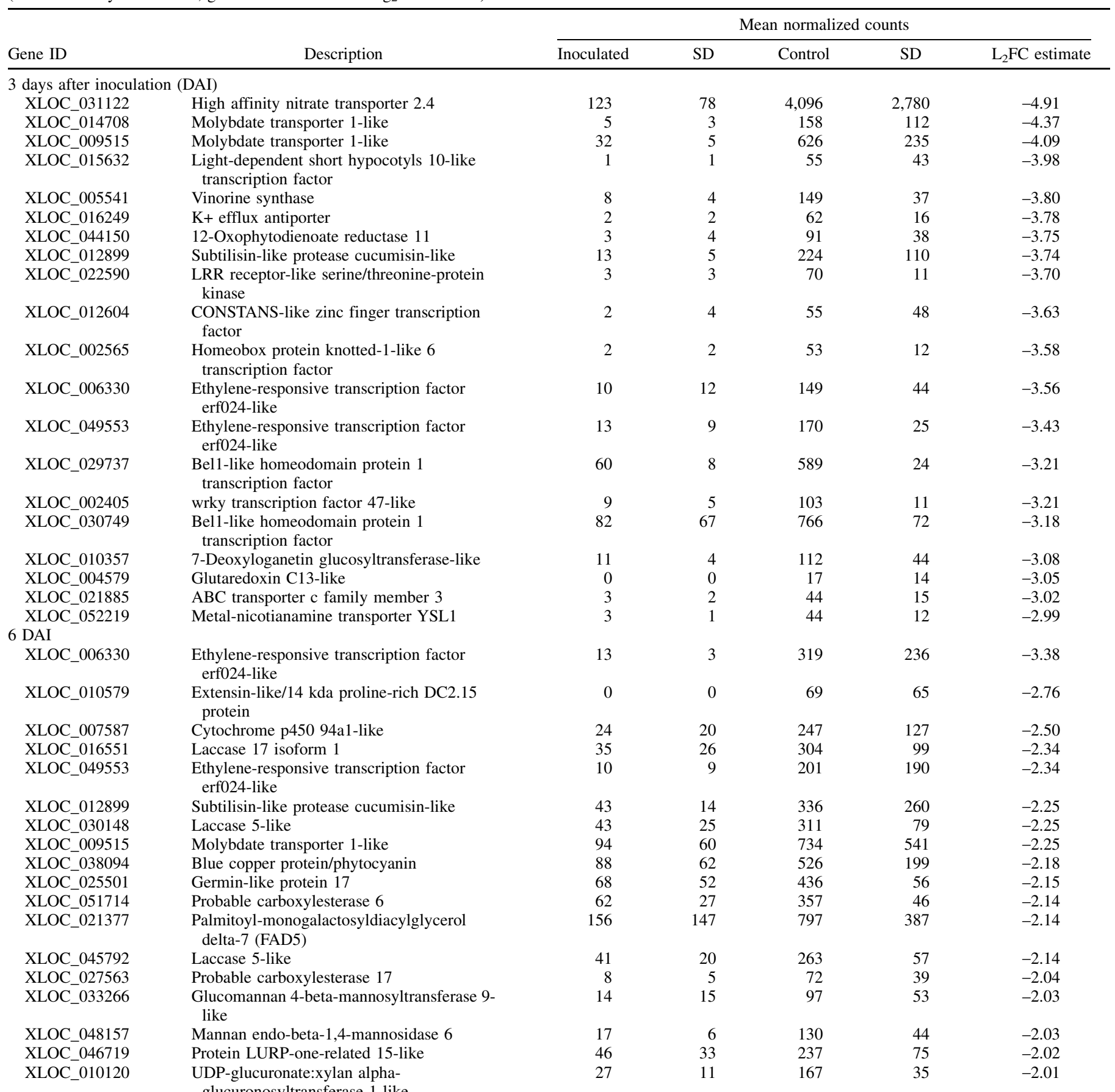


inoculated samples contained multiple vermiform females embedded in the root cortex with their head regions adjacent to the stele. At 6 DAI, individual root samples contained a mixture of infection stages: both vermiform females and swollen females were present, indicating a mixture of new and mature feeding sites. At $9 \mathrm{DAI}$, all females were swollen into the characteristic mature reniform shape, and at 12 DAI, egg masses were present at the majority of infection sites. In no samples was there evidence of rhizobial nodules or nodule primordia.

Assembly and differential gene expression. Illumina sequencing of 24 RNA samples from reniform nematode-inoculated and control roots generated over 300 million 100-bp reads. After filtering and trimming, clean reads from all samples were mapped back to the soybean reference genome, and transcripts were assembled using soybean reference gene models as guidance. The final soybean root transcriptome contained both previously annotated and novel transcripts. In total, we assembled 46,995 unique genes and 120,565 alternate splice forms of these genes, with an N50 of 1,430 bp and a mean length of $984 \mathrm{bp}$. Ninety-seven percent of the assembled genes received a significant hit to the NCBI $\mathrm{nr}$ database $\left(\mathrm{E}<10^{-6}\right)$, and $79 \%$ were annotated with at least one GO term. Enzyme codes and KEGG pathways were assigned to 21 and $26 \%$ of the assembled genes, respectively. The FASTA sequences of all assembled transcripts are provided in Supplementary File S1, and Blast2GO transcript annotations, including Glyma names of previously annotated genes, are provided in Supplementary File S2.

Overall patterns of differential gene expression. Exploratory data visualization with principal components analysis (PCA)

TABLE 2. (Continued from previous page)

\begin{tabular}{|c|c|c|c|c|c|c|}
\hline \multirow[b]{2}{*}{ Gene ID } & \multirow[b]{2}{*}{ Description } & \multicolumn{5}{|c|}{ Mean normalized counts } \\
\hline & & Inoculated & SD & Control & SD & $\mathrm{L}_{2} \mathrm{FC}$ estimate \\
\hline XLOC_035373 & Sugar transporter ERD6-like 16 & 15 & 8 & 611 & 985 & -2.00 \\
\hline XLOC_025490 & ATP binding cassette B family member 4 & 28 & 13 & 147 & 75 & -1.96 \\
\hline \multicolumn{7}{|l|}{9 DAI } \\
\hline XLOC_006330 & $\begin{array}{l}\text { Ethylene-responsive transcription factor } \\
\text { erf024-like }\end{array}$ & 4 & 2 & 123 & 19 & -4.05 \\
\hline XLOC_002565 & $\begin{array}{l}\text { Homeobox protein knotted-1-like } 6 \\
\text { transcription factor }\end{array}$ & 0 & 0 & 38 & 1 & -3.38 \\
\hline XLOC_012899 & Subtilisin-like protease cucumisin-like & 7 & 5 & 161 & 133 & -3.23 \\
\hline XLOC_007587 & Cytochrome p450 94a1-like & 31 & 17 & 282 & 82 & -2.93 \\
\hline XLOC_049553 & $\begin{array}{l}\text { Ethylene-responsive transcription factor } \\
\text { erf024-like }\end{array}$ & 5 & 3 & 67 & 17 & -2.89 \\
\hline XLOC_027563 & Probable carboxylesterase 17 & 3 & 1 & 53 & 33 & -2.85 \\
\hline XLOC_039814 & $\begin{array}{l}\text { Ethylene-responsive transcription factor } \\
\text { erf024-like }\end{array}$ & 2 & 1 & 44 & 1 & -2.85 \\
\hline XLOC_031122 & High affinity nitrate transporter 2.4 & 129 & 54 & 1,464 & 853 & -2.72 \\
\hline XLOC_044314 & WUSCHEL-related homeobox 4-like & 1 & 1 & 31 & 22 & -2.58 \\
\hline XLOC_002206 & E3 ubiquitin-protein ligase RHA1B-like & 29 & 15 & 189 & 55 & -2.48 \\
\hline XLOC_019263 & Auxin-induced protein 5NG4 & 47 & 27 & 278 & 90 & -2.40 \\
\hline XLOC_047728 & Nitrate transporter 1.2-like & 14 & 3 & 89 & 15 & -2.28 \\
\hline XLOC_035906 & High affinity nitrate transporter 2.4-like & 1,108 & 530 & 7,295 & 4,942 & -2.27 \\
\hline XLOC_043785 & $\begin{array}{l}\text { Extensin-like/14 kda proline-rich DC2.15 } \\
\text { protein }\end{array}$ & 9 & 10 & 99 & 62 & -2.25 \\
\hline XLOC_038778 & $\begin{array}{l}\text { Fasciclin-like arabinogalactan protein 11- } \\
\text { like }\end{array}$ & 185 & 220 & 915 & 773 & -2.20 \\
\hline XLOC_000520 & Sugar phosphate translocator at3g11320-like & 3 & 5 & 39 & 53 & -2.14 \\
\hline XLOC_029801 & High affinity nitrate transporter 2.4 & 458 & 364 & 2,069 & 167 & -2.14 \\
\hline XLOC_035435 & $\begin{array}{l}\text { Fasciclin-like arabinogalactan protein 11- } \\
\text { like }\end{array}$ & 297 & 303 & 1,435 & 1,140 & -2.12 \\
\hline XLOC_030739 & Momilactone A synthase & 63 & 33 & 300 & 86 & -2.11 \\
\hline XLOC_030910 & $\begin{array}{l}\text { Pleckstrin domain-containing family } \mathrm{N} \\
\text { member } 1\end{array}$ & 7 & 8 & 46 & 26 & -2.06 \\
\hline \multicolumn{7}{|l|}{$12 \mathrm{DAI}$} \\
\hline XLOC_036897 & Alcohol dehydrogenase 1 & 1 & 2 & 49 & 41 & -2.51 \\
\hline XLOC_012481 & Ring-h2 finger protein ATL78-like & 5 & 2 & 55 & 39 & -2.23 \\
\hline XLOC_028025 & Polyol transporter 3-like & 285 & 173 & 1,338 & 560 & -2.11 \\
\hline XLOC_041911 & CEN-like protein 1 & 100 & 60 & 465 & 104 & -2.00 \\
\hline XLOC_024315 & Dehydrin-like protein & 7 & 7 & 65 & 81 & -1.87 \\
\hline XLOC_020262 & Trypsin inhibitor A & 11 & 12 & 178 & 287 & -1.84 \\
\hline XLOC_021091 & Ring-h2 finger protein ATL78-like & 36 & 22 & 185 & 75 & -1.83 \\
\hline XLOC_020147 & gdsl esterase lipase & 78 & 41 & 474 & 341 & -1.83 \\
\hline XLOC_007303 & Glucan endo-1,3-beta-glucosidase-like & 996 & 993 & 4,017 & 2,077 & -1.81 \\
\hline XLOC_000098 & Hydroxyproline-rich glycoprotein & 61 & 43 & 249 & 96 & -1.78 \\
\hline XLOC_018422 & Ankyrin repeat protein & 12 & 3 & 65 & 16 & -1.73 \\
\hline XLOC_043206 & Late embryogenesis abundant protein LEA5 & 127 & 88 & 771 & 790 & -1.71 \\
\hline XLOC_031220 & $\begin{array}{l}\text { Cysteine-rich repeat secretory protein } 38 \text { - } \\
\text { like }\end{array}$ & 23 & 12 & 102 & 54 & -1.65 \\
\hline XLOC_049742 & Galactinol synthase & 434 & 215 & 1,624 & 995 & -1.64 \\
\hline XLOC_006648 & $\begin{array}{l}\text { cbl-interacting serine threonine-protein } \\
\text { kinase 9-like }\end{array}$ & 32 & 14 & 122 & 42 & -1.63 \\
\hline XLOC_013822 & $\begin{array}{l}\text { LRR receptor-like serine threonine-protein } \\
\text { kinase at } 2 \mathrm{~g} 24130 \text {-like }\end{array}$ & 57 & 58 & 191 & 76 & -1.59 \\
\hline XLOC_013725 & Cyclic dof factor 3-like transcription factor & 69 & 29 & 258 & 132 & -1.58 \\
\hline XLOC_039767 & Ovate family protein transcription factor & 70 & 25 & 236 & 64 & -1.56 \\
\hline XLOC_003515 & $\begin{array}{l}\text { LRR receptor-like serine threonine-protein } \\
\text { kinase at1g06840-like }\end{array}$ & 161 & 8 & 540 & 163 & -1.54 \\
\hline XLOC_014835 & Cryptochrome 1 & 71 & 17 & 260 & 105 & -1.51 \\
\hline
\end{tabular}


confirmed that samples could be separated by infection status along one of the first two principal components at 3, 9, and 12 DAI (Fig. 2). There was no clear separation of samples by infection status at 6 DAI (see below). Sequence descriptions, normalized counts, $\log _{2} \mathrm{FC}$ estimates, and FDR adjusted $P$ values for all genes on all dates are provided in Supplementary Files S3, S4, S5, and S6.

A total of 6,628 genes were differentially expressed (DE) between inoculated and control roots on at least one sampling date (Fig. 3; FDR $=0.01 ;\left|\log _{2} \mathrm{FC}\right| \geq 1$ ). The greatest number of DE genes $(6,021)$ was observed early in the infection process on DAI 3 . There were far fewer DE genes on later dates (Fig. 3). The magnitude of differential expression was also highest on DAI 3, when estimated $\log _{2} \mathrm{FC}$ values for individual DE genes ranged from -5.24 to 8.75. The fold changes of DE genes on subsequent dates were orders of magnitude smaller: $\log _{2} \mathrm{FC}$ ranges were -3.38 to 4.11 (6 DAI), -4.05 to 4.06 (9 DAI), and -3.00 to 4.72 (12 DAI).

More genes were up-regulated than down-regulated in infected roots: 4,000 up-regulated versus 2,021 down-regulated (3 DAI), 773 versus 296 (9 DAI), and 458 versus 64 (12 DAI). The exception occurred on DAI 6, when only a small number of DE genes were identified, and more were down-regulated ( 72 versus 138 ). In a separate experiment, we observed a similar phenomenon during reniform nematode infection of cotton roots: high variability among samples and fewer DE genes at 6 DAI compared with 3, 9, and 12 DAI. This result may reflect the presence of multiple infection stages at 6 DAI (Fig. 1), a result we have documented histologically in both soybean and cotton.

Top differentially expressed genes. Tables 1 and 2 present the top $20 \mathrm{DE}$ genes with the largest positive and negative $\log _{2} \mathrm{FC}$ estimates on each sampling date. Many of the top 20 up-regulated genes on each date coded for nodulins, nodulation-specific proteins, and/or proteins with a documented role in nodulation (Table 1 ). This trend was most apparent at 3 DAI, when 16 of the top 20 upregulated genes were known to be associated with nodulation. A total of 5,8, and 11 of the top 20 up-regulated genes at 6,9 , and 12 DAI also had documented roles in nodulation. The magnitude of upregulation for some nodulation-related genes was extremely high: at $3 \mathrm{DAI}, \log _{2} \mathrm{FC}$ estimates for eight nodulation-related genes were greater than 8.0 (i.e., a 256-fold increase).

The top up-regulated gene list contained nodulin-16 (a membrane protein), nodulin-21 (an iron transporter), nodulin-41 (an aspartic protease), and nodulin-61 (a FluG glutamate-ammonia ligase). Other well-known nodulation genes included CERBERUS/LIN-1, the NODULE INCEPTION transcription factor NIN, the nodulespecific zinc transporter ZIP1, and a soybean homolog of ROOT DETERMINED NODULATION 1.

The top up-regulated gene list also contained multiple genes related to defense (defensin- and thaumatin-like proteins, endochitinase, and tmv resistance protein), stress and reactive oxygen detoxification (universal stress protein A, numerous peroxidases, and GDPmannose-epimerase), modification and degradation of proteins (several proteases and ring-h2 finger proteins), and the metabolism of gibberellic acid (ent-copalyl diphosphate synthase and gibberellin 20 oxidase 1) and ethylene (1-aminocyclopropane-1-carboxylate oxidase).

Two strongly induced genes coded for transcription factors: NIN and a bHLH30-like transcription factor. In contrast, 12 transcription factors appeared on the top down-regulated gene list, three of them ethylene response factors (ERFs, Table 2). ERFs control plant responses to pathogens through the regulation of jasmonate (JA)/ ethylene (ET) responsive defense genes (Huang et al. 2016); their downregulation is consistent with nematode-induced suppression of the plant immune system. Also, strongly down-regulated were genes associated with jasmonic acid metabolism (12-oxophytodienoate reductase and cytochrome p450 94a1) and the transport and response to auxin (ATP binding cassette B family member 4, auxin-induced protein $5 \mathrm{NG} 4$, and cryptochrome 1 ).

Numerous cell wall genes were down-regulated, including those associated with lignin metabolism (laccases), hemicellulose metabolism (glucomannan 4- $\beta$-mannosyltransferase, mannan endo- $\beta$-1,4 mannosidase, and UDP-glucuronate:xylan alpha-glucuronosyltransferase), cell adhesion (fasciclin-like arabinogalactan proteins), and cell wall strengthening (extensins and hydroxyproline-rich glycoproteins).

Gene set enrichment analysis. In parallel with the identification of individual DE genes, GSEA was used to identify predefined gene sets whose expression differed between inoculated and control roots on each date (FDR $=0.05$; Fig. 4). While DESeq2 identifies individual genes with large, statistically significant fold changes, GSEA identifies gene sets whose individual members show concordant, but potentially smaller, differences in expression between treatments (Subramanian et al. 2005). Five hundred and seven gene sets were significantly enriched or depleted in infected roots on at least one sampling date: 303 enriched in infected roots, 169 depleted, and 35 either enriched or depleted, depending on the date. The top 20 gene sets significantly enriched in infected roots on each date are presented in Table 3, and normalized enrichment scores for all gene sets are provided in Supplementary File S7.

Some enriched gene sets confirmed the results of the differential gene expression analysis. The gene set GO:0009877 (nodulation) was significantly enriched in infected roots on all sampling dates and was among the top 20 enriched gene sets at 6 and 9 DAI (Table 3). The related gene set GO:0009399 (nitrogen fixation) was also significantly enriched on all sampling dates. BLASTx results confirmed that all genes with these GO annotations were plant genes, most of them previously annotated in the soybean reference genome. None were of bacterial origin.

The gene set MAP00940 (phenylpropanoid biosynthesis) was significantly enriched in infected roots on all dates, and the related gene sets GO:0016210 (naringenin-chalcone synthase activity), MAP00943 (isoflavonoid biosynthesis), MAP00941 (flavonoid biosynthesis), and GO:0009813 (flavonoid biosynthetic process) were all significantly enriched at 3 DAI. While flavonoids in general have broad roles in plant development and defense, isoflavonoids such as narigenin serve as chemical messengers between legumes and their bacterial symbionts and have been shown to increase during nematode infection (Hutangura et al. 1999; Kennedy et al. 1999; Liu and Murray 2016).

By far the largest number of top enriched gene sets were related to DNA: its packaging, modification, and replication, as well as the accompanying process of mitosis (Table 3). Many of these sets were significantly enriched on at least three dates, including GO:0003678 (DNA helicase activity), GO:0006270 (DNA replication initiation), GO:0000786 (nucleosome), GO:0051567 (Histone H3-K9 methylation), GO:0042555 (MCM complex), and GO:0010389 (regulation of G2/M transition of mitotic cell cycle).

Enrichment at 3 DAI of gene sets related to large ribosomal subunits (GO:0015934), small ribosomal subunits (GO:0015935), and rRNA binding (GO:0019843) suggested that early stages of reniform nematode symbiosis were characterized by wholesale induction of translational machinery and de novo protein synthesis (Table 3). Enrichment of genes sets related to aerobic respiration (GO:0009060, GO:0005747, and GO:0004129) on multiple dates was consistent with enhanced energy demand and cellular respiration. Enrichment of gene sets related to pectin catabolism suggested that pectin degradation may occur in cell walls and middle lamellae during reniform nematode infection (EC:3.1.1.11, GO:0030599, and GO:0045490).

While pectin catabolism genes were enriched, far more cell wallrelated gene sets were depleted. At 3 DAI, four gene sets related to 1,3beta-glucan (callose) synthase activity were depleted in infected roots (Table 4). At 6 DAI, expression of multiple cell wall gene sets was depleted, including those associated with general wall properties (GO: 0042546, GO:0071555), pectin synthesis (GO:004589, EC.2.4.1.43), hemicellulose synthesis (GO:0010417, GO:0010413), and lignin metabolism (EC:1.10.3.2, GO:0046274). Many of these same sets were enriched at 12 DAI, consistent with a switch from wall thinning and lysing in early infection to later wall thickening in mature feeding sites (Rebois et al. 1975). 
Also depleted in infected roots were gene sets related to blue light signaling. These included phototropism (GO:0009638), blue light signaling pathway (GO:0009785), and blue light photoreceptor activity (GO:0009882). Inspection of the leading-edge genes from the depleted sets (i.e., the specific genes responsible for the depletion signal) showed that in all cases the signal was related to repression of four cryptochrome 1 genes (XLOC_009646, XLOC_014716, XLOC_034413, and XLOC_037027), two cryptochrome 2 genes (XLOC_039443 and XLOC_002396), and one phytochrome A gene (XLOC_025512). Down-regulation of these genes was most marked at 3 DAI but, in some cases, continued into later stages of syncytium formation.

Expression of nodulation-related genes. Of the 59 genes in the Nodulation (GO:0009877) gene set, 50 contributed to its leading edge on at least one date. Expression data for these and 81 additional nodulation-related genes identified from the assembled transcriptome are presented as clustered heat maps in Figure 5 (up-regulated genes) and Figure 6 (down-regulated and unchanged genes). The most pronounced differences in nodulation-related gene expression occurred early in the infection process at 3 DAI. Ninety-nine putative nodulationrelated genes were significantly up-regulated at $3 \mathrm{DAI}$, compared with 6,20 , and 18 at 6, 9, and 12 DAI, respectively. Nineteen nodulationrelated genes were down-regulated at 3 DAI compared with three, five, and zero at 6,9 , and 12 DAI.
Multiple genes that participate in the canonical signal transduction pathway of nodule initiation were strongly up-regulated in infected roots. These included the transcriptional activator CYCLOPS (up-regulated 5.5-fold at $3 \mathrm{DAI}$ ) and four soybean homologs of the NODULE INCEPTION (NIN) transcription factor to which CYCLOPS binds (up-regulated 6- to 188.7-fold at 3 DAI). Also induced were soybean homologs of the GRAS-family transcription factors NODULATION SIGNALING PATHWAY 1 (NSP1, up 3.5-fold) and NODULATION SIGNALING PATHWAY 2 (NSP2, up 10.3-fold), which bind the promoters of early nodulin genes. Components of signal transduction events associated with the autoregulation of nodulation (AON) program were also induced. These included a homolog of ROOT DETERMINED NODULATION 1 (RDN1, up 123.6-fold at 3 DAI) and five plant CLAVATA3/ESR family (CLE) proteins (up 2.7- to 8.3fold at $3 \mathrm{DAI})$.

Additional nodulins and nodulation-related genes, many of which act downstream of the transcription factors above, were also induced by reniform nematode parasitism. These spanned a wide range of functions, from membrane transporters (NIP aquaglyceroporins, SWEET bidirectional sugar uniporters, vacuolar iron transporters, and a nodule-specific zinc transporter) to lipid raft components (remorins and flotillins) to proteins involved in remodeling of the extracellular matrix (pectate lyases and extensin-like/proline-rich proteins). Some

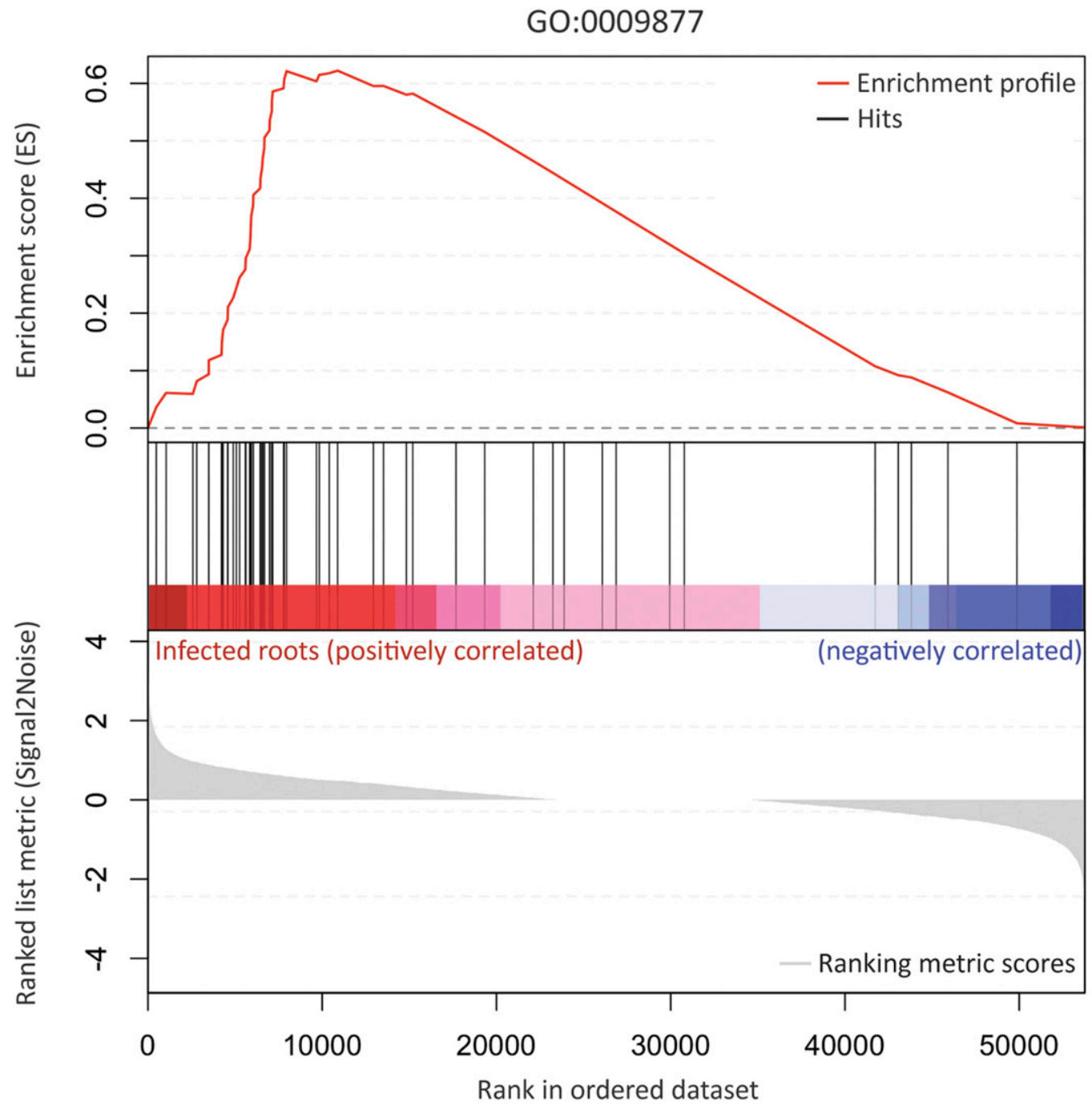

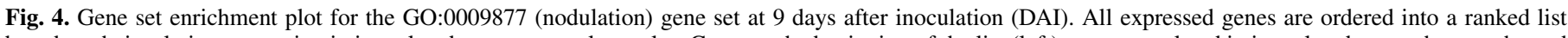

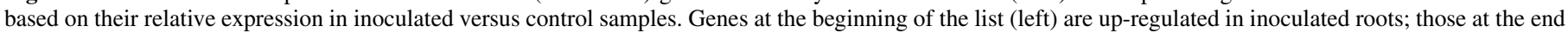

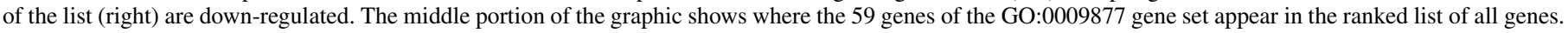

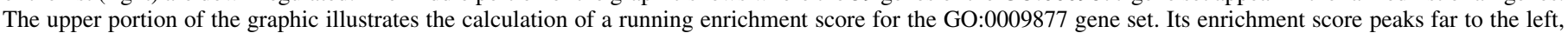

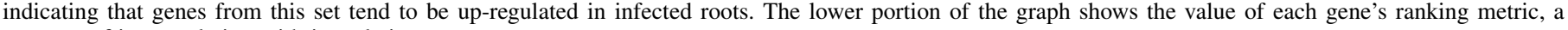
measure of its correlation with inoculation status. 
were nodulins of unknown function that have been previously annotated only as peribacteroid membrane components (e.g., ENOD 55-2, nodulin-24, nodulin-20, and nodulin-16). Others were associated with cell cycle control and endoreduplication (cyclindependent kinase inhibitor 7, E2Fa, and FIZZY-RELATED 3). Of particular interest was the significant up-regulation of nodulation genes that have no obvious role in nematode parasitism, such as the three leghemoglobin genes induced 8.3- to 11.5-fold at 3 DAI. It is unclear whether these genes are required for reniform nematode parasitism, or whether their induction is incidental to nematode manipulation of high level regulatory programs also involved with nodulation.

A smaller number of putative nodulation-related genes were downregulated during reniform nematode infection. Several were from families also present in the up-regulated gene set, such as remorins, SWEET sugar transporters, a CLAVATA/ESR (CLE) protein, and an RDN-1/o-arabinosyl transferase. Others were from families not present in the up-regulated gene list, and many of these had putative roles in defense. Five of the down-regulated nodulation-related genes coded for phospholipase D, which generates phosphatidic acid (PA) in response to bacterial Nod factors, and functions in perception and response to bacterial, fungal, and nematode pathogens (Zhao 2015). Two genes coding for nodulin-related protein 1, previously linked to heat stress and defense signaling, were also significantly downregulated during infection (Fu et al. 2010).

\section{DISCUSSION}

Reniform nematode infection begins when an immature female penetrates the root epidermis and cortex to reach an endodermal "initial cell." There she inserts her stylet and releases a mixture of effectors, including both CLE and CEP peptide mimics (Eves-Van den Akker et al. 2016; Wubben et al. 2015). The initial cell and adjacent pericycle cells exhibit areas of cell wall lysing, which ultimately converge into full breaks, allowing multiple cytoplasms to coalesce into a single syncytium. Previous work suggests that feeding site formation is initiated by 2 to 3 DAI and that syncytia are well established by 6 to 9 DAI (Agudelo et al. 2005; Jones and Dropkin 1975; Rebois 1980; Rebois et al. 1975). Our histological results were consistent with this time course.

Uninfected root pericycle cells are dominated by a large central vacuole, with a relatively small amount of cytoplasm confined to the cell periphery. During feeding site formation, the central vacuoles of affected cells are disassembled and the numbers of ribosomes, mitochondria, plastids, and small vacuoles increase. Together with an increase in the size of endoplasmic reticula and nuclei, these changes

TABLE 3. Top 20 gene sets whose expression was significantly enriched in reniform nematode-infected soybean roots at four time points after inoculation (false discovery rate $=0.05$; gene sets ranked by gene set enrichment analysis normalized enrichment score)

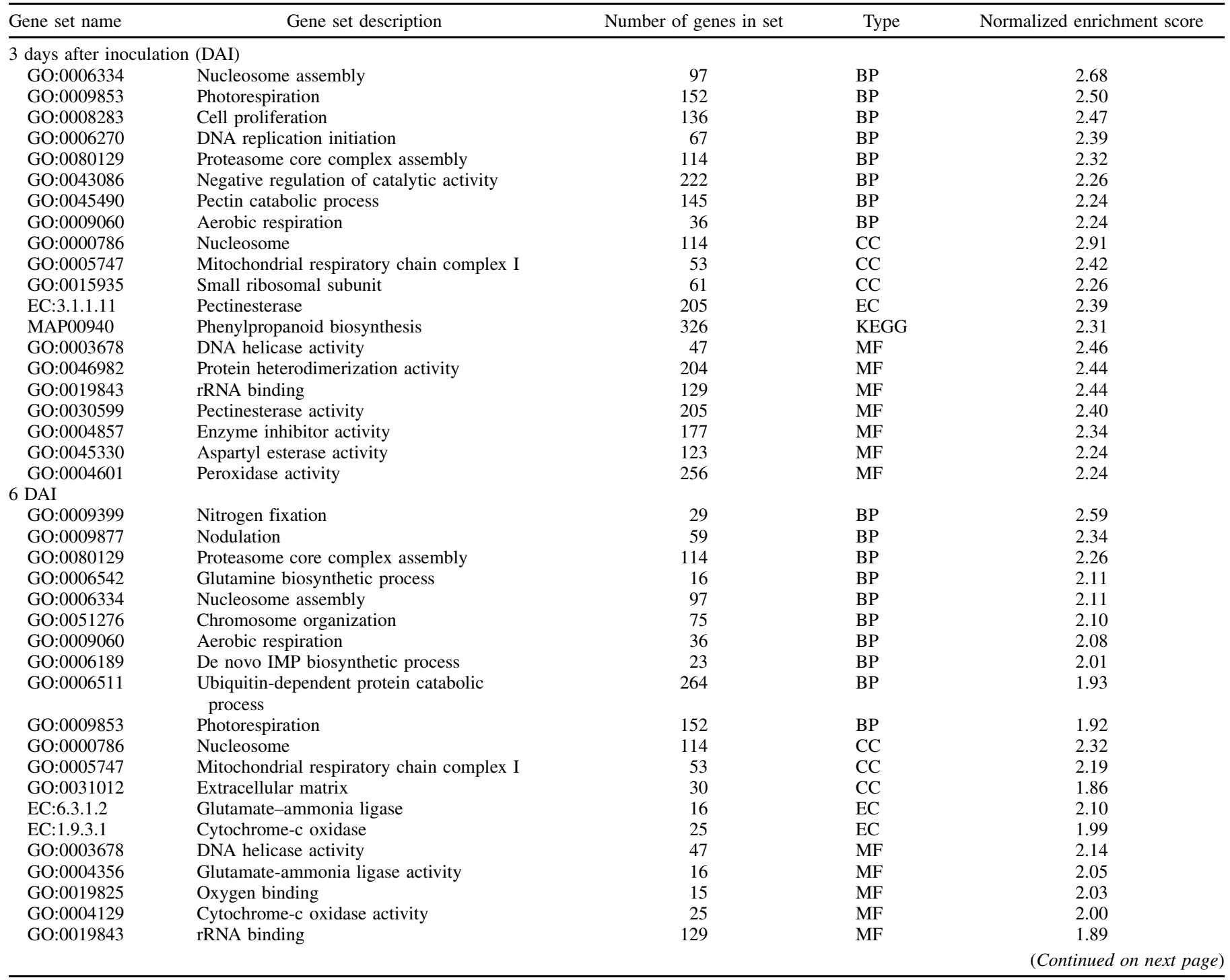


fill syncytial cells with a dense, organelle-rich cytoplasm (Agudelo et al. 2005; Rebois et al. 1975). The number of incorporated pericycle cells increases outwardly from the initial cell as the syncytium develops, ultimately encompassing 100 to 200 cells. Remaining portions of the syncytial cell walls thicken and may display ingrowths and complex "boundary formations" (Agudelo et al. 2005; Rebois et al. 1975). Although the broad ultrastructural changes that accompany infection have been documented, relatively little is known about infection-related changes in plant gene expression.

General trends in gene expression during reniform nematode infection. The most substantial changes in gene expression occurred early in infection. A subset of genes was differentially expressed throughout the full 12-day time course, but the largest number of DE genes and the largest differences in gene expression were observed at 3 DAI.

Many DE genes and gene sets were consistent with ultrastructural changes previously reported during infection. Genes involved in cell wall synthesis and organization were suppressed early in infection when cell walls have been shown to lyse, then up-regulated in later stages when they have been reported to thicken and develop in-growths (Agudelo et al. 2005; Rebois et al. 1975). Likewise, genes and gene sets associated with aerobic respiration and ribosomal biogenesis were markedly up-regulated in infected roots, consistent with the documented proliferation of mitochondria and ribosomes in syncytial cells. It should be noted that we sampled whole infected roots, not syncytia alone. Gene expression changes therefore represent the aggregate response of the root system as a whole, including but not limited to, the responses of syncytial cells.

Many genes and gene sets induced during infection had previously documented roles in rhizobial nodule formation. Nodulationrelated genes are not unique to legumes, nor are they expressed only during nodulation (Denance et al. 2014). They have been most extensively studied in the context of legume nodulation, but they have homologs in nonlegume species and function in multiple developmental and symbiotic contexts. Many instances of overlap among genes involved in mycorrhization, nodulation, and nematode parasitism have been reported previously (reviewed in Mathesius 2003). For example, nodulin $\mathrm{N}-26$, which encodes an aquaglyceroporin, is also induced during mycorrhizal infection, RKN gall formation, and reniform nematode parasitism (Albrecht et al. 1999; Favery et al. 2002). Likewise, the leucine-rich repeat (LRR) receptor kinase SYMRK/ NORK is part of a receptor complex that functions in plant perception of rhizobia, mycorrhizal fungi, and RKN (Endre et al. 2002; Stracke et al. 2002; Weerasinghe et al. 2005). Nonetheless, the number and magnitude of differentially expressed nodulation-related genes observed during reniform nematode parasitism of soybean was unexpected.

Reniform nematodes may exploit aspects of the same signal exchange pathways used by rhizobia to communicate with their legume hosts. This possibility has previously been raised for the endoparasitic RKN Meloidogyne incognita, which possesses a horizontally acquired gene homologous to that of rhizobial nodL (Bellafiore et al. 2008; McCarter et al. 2003). In response to root-derived flavonoids, rhizobial nodL

TABLE 3. (Continued from previous page)

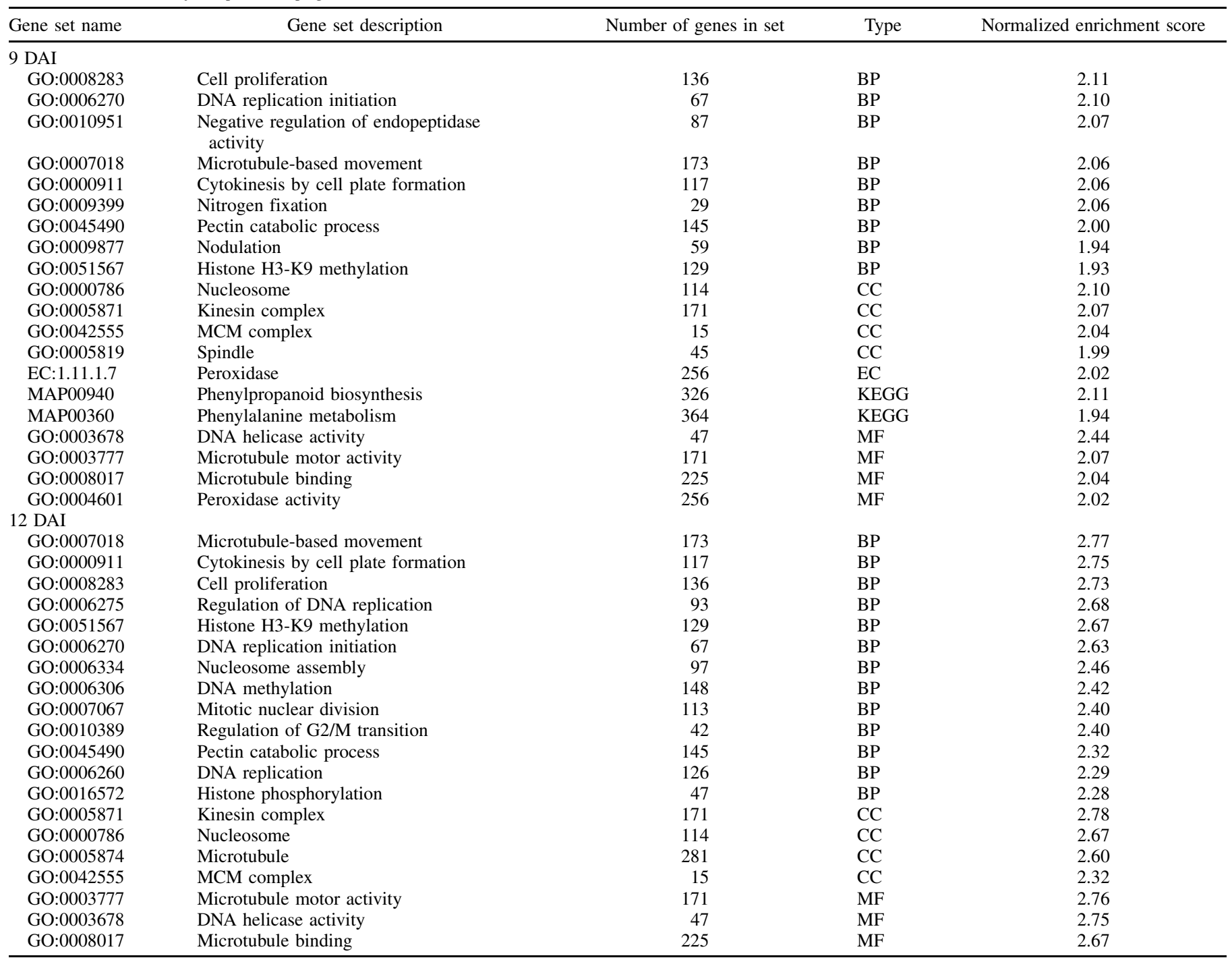


promotes production of Nod factors that trigger nodule formation on host roots. It is not yet clear whether the $M$. incognita nodL gene promotes synthesis of nematode "Nod factors" that similarly trigger aspects of feeding site formation. Nonetheless, the wholesale induction of nodulation-related genes reported here suggests that reniform nematode may also modulate high-level regulators shared with the nodulation program.

Nodulation-related genes: Early signaling events and autoregulation of nodulation. Legumes signal to rhizobia through the secretion of specific flavonoids that promote synthesis and release of bacterial Nod factors (Ferguson et al. 2010). In L. japonica, Nod factors diffuse to the root epidermis, where they bind to a receptor complex consisting of NFR1, NFR5, and SYMRK/NORK recruited by flotillin FLOT4 to lipid rafts (Madsen et al. 2003). Protein interactions and phosphorylations generate a signaling cascade that ultimately initiates a cytosolic calcium spike perceived by calcium/ calmodulin-dependent protein kinase (CCaMK). CCaMK binds and phosphorylates the transcription factor CYCLOPS, which in turn induces expression of NIN, a transcriptional regulator of multiple nodulation genes including pectate lyase (Singh et al. 2014; Xie et al.

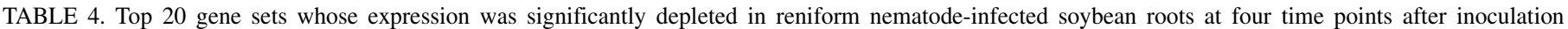
(false discovery rate $=0.05$; gene sets ranked by gene set enrichment analysis normalized enrichment score) ${ }^{\mathrm{a}}$

\begin{tabular}{|c|c|c|c|c|}
\hline Gene set name & Description & Total genes in set & Type & Normalized enrichment score \\
\hline \multicolumn{5}{|c|}{3 days after inoculation (DAI) } \\
\hline GO:0043531 & ADP binding & 380 & MF & -2.86 \\
\hline GO:0004012 & Phospholipid-translocating ATPase activity & 34 & MF & -2.55 \\
\hline GO:0045332 & Phospholipid translocation & 34 & $\mathrm{BP}$ & -2.52 \\
\hline GO:0019829 & Cation-transporting ATPase activity & 60 & MF & -2.51 \\
\hline EC:3.6.3.1 & Phospholipid-translocating ATPase & 34 & $\mathrm{EC}$ & -2.50 \\
\hline GO:0000956 & $\begin{array}{l}\text { Nuclear-transcribed mRNA catabolic } \\
\text { process }\end{array}$ & 66 & $\mathrm{BP}$ & -2.43 \\
\hline EC:2.4.1.34 & 1,3-Beta-glucan synthase & 30 & $\mathrm{EC}$ & -2.43 \\
\hline GO:0006075 & 1,3-Beta-D-glucan biosynthetic process & 30 & $\mathrm{BP}$ & -2.37 \\
\hline GO:0003843 & 1,3-Beta-D-glucan synthase activity & 30 & MF & -2.37 \\
\hline GO:0000148 & 1,3-Beta-D-glucan synthase complex & 30 & $\mathrm{CC}$ & -2.33 \\
\hline GO:0008026 & ATP-dependent helicase activity & 159 & MF & -2.31 \\
\hline GO:0098655 & Cation transmembrane transport & 108 & $\mathrm{BP}$ & -2.30 \\
\hline GO:0036459 & Ubiquitinyl hydrolase activity & 57 & MF & -2.25 \\
\hline GO:0004386 & Helicase activity & 181 & MF & -2.25 \\
\hline GO:0009638 & Phototropism & 18 & $\mathrm{BP}$ & -2.24 \\
\hline GO:0010119 & Regulation of stomatal movement & 46 & $\mathrm{BP}$ & -2.22 \\
\hline GO:0006487 & Protein N-linked glycosylation & 107 & $\mathrm{BP}$ & -2.21 \\
\hline GO:0023014 & $\begin{array}{l}\text { Signal transduction by protein } \\
\text { phosphorylation }\end{array}$ & 60 & $\mathrm{BP}$ & -2.17 \\
\hline GO:0009785 & Blue light signaling pathway & 25 & $\mathrm{BP}$ & -2.17 \\
\hline $\mathrm{EC}: 2.7 .3$ & $\begin{array}{l}\text { Phosphotransferases with a nitrogenous } \\
\text { group as acceptor }\end{array}$ & 55 & $\mathrm{EC}$ & -2.16 \\
\hline \multicolumn{5}{|c|}{ 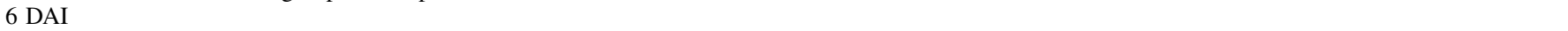 } \\
\hline GO:0009834 & Plant-type secondary cell wall biogenesis & 46 & $\mathrm{BP}$ & -2.52 \\
\hline $\mathrm{EC}: 1.10 .3 .2$ & Laccase & 58 & EC & -2.38 \\
\hline GO:0052716 & $\begin{array}{l}\text { Hydroquinone:oxygen oxidoreductase } \\
\text { activity }\end{array}$ & 58 & $\mathrm{MF}$ & -2.37 \\
\hline GO:0046274 & Lignin catabolic process & 58 & $\mathrm{BP}$ & -2.36 \\
\hline GO:0010417 & Glucuronoxylan biosynthetic process & 22 & $\mathrm{BP}$ & -2.29 \\
\hline GO:0010089 & Xylem development & 81 & $\mathrm{BP}$ & -2.29 \\
\hline GO:0045489 & Pectin biosynthetic process & 26 & $\mathrm{BP}$ & -2.19 \\
\hline GO:0042546 & Cell wall biogenesis & 49 & $\mathrm{BP}$ & -2.15 \\
\hline GO:0010413 & Glucuronoxylan metabolic process & 138 & $\mathrm{BP}$ & -2.13 \\
\hline GO:0009832 & Plant-type cell wall biogenesis & 94 & $\mathrm{BP}$ & -2.12 \\
\hline GO:0045492 & Xylan biosynthetic process & 139 & $\mathrm{BP}$ & -2.12 \\
\hline GO:0000139 & Golgi membrane & 207 & $\mathrm{CC}$ & -2.11 \\
\hline GO:0018298 & Protein-chromophore linkage & 81 & $\mathrm{BP}$ & -2.06 \\
\hline GO:0071555 & Cell wall organization & 362 & $\mathrm{BP}$ & -2.06 \\
\hline $\mathrm{EC}: 2.4 .1 .43$ & $\begin{array}{l}\text { Polygalacturonate } 4 \text {-alpha- } \\
\text { galacturonosyltransferase }\end{array}$ & 28 & $\mathrm{EC}$ & -2.06 \\
\hline GO:0048519 & Negative regulation of biological process & 44 & $\mathrm{BP}$ & -2.05 \\
\hline MAP00532 & $\begin{array}{l}\text { Glycosaminoglycan biosynthesis } \\
\text { chondroitin sulfate }\end{array}$ & 27 & KEGG & -2.05 \\
\hline GO:0008361 & Regulation of cell size & 58 & $\mathrm{BP}$ & -2.04 \\
\hline GO:0031225 & Anchored component of membrane & 97 & $\mathrm{CC}$ & -2.03 \\
\hline GO:0010051 & Xylem and phloem pattern formation & 59 & $\mathrm{BP}$ & -2.02 \\
\hline \multicolumn{5}{|l|}{9 DAI } \\
\hline GO:0043531 & ADP binding & 380 & MF & -2.29 \\
\hline GO:0009785 & Blue light signaling pathway & 25 & $\mathrm{BP}$ & -2.20 \\
\hline GO:0071702 & Organic substance transport & 20 & $\mathrm{BP}$ & -1.98 \\
\hline GO:0044444 & Cytoplasmic part & 88 & $\mathrm{CC}$ & -1.94 \\
\hline GO:0009882 & Blue light photoreceptor activity & 15 & $\mathrm{MF}$ & -1.94 \\
\hline \multicolumn{5}{|l|}{12 DAI } \\
\hline GO:0043531 & ADP binding & 380 & $\mathrm{MF}$ & -2.17 \\
\hline GO:0000956 & $\begin{array}{l}\text { Nuclear-transcribed mRNA catabolic } \\
\text { process }\end{array}$ & 66 & $\mathrm{BP}$ & -2.03 \\
\hline
\end{tabular}

a On 9 and 12 DAI, fewer than 20 gene sets were significantly depleted. 


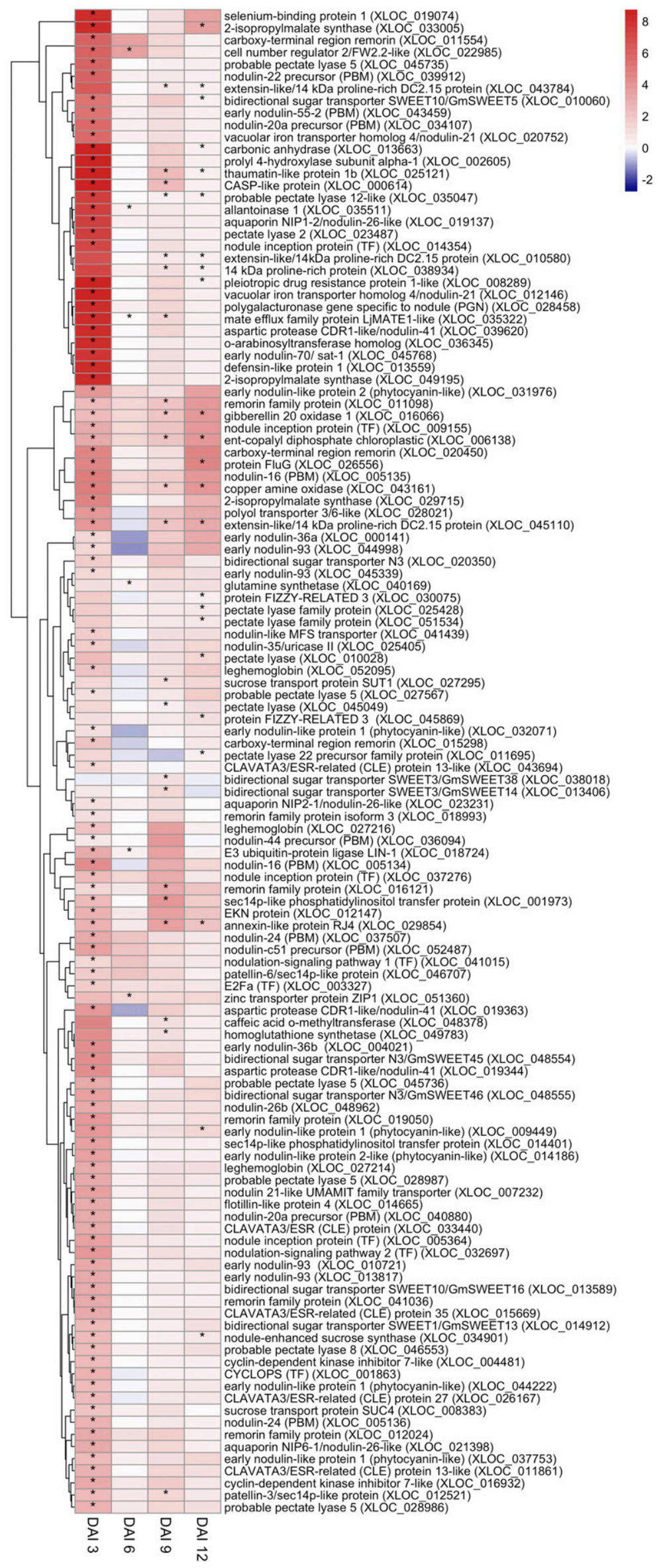

Fig. 5. Clustered heatmap of $\log _{2} \mathrm{FC}$ estimates for up-regulated nodulins and nodulation-related genes in soybean roots. Red and blue indicate up- and downregulation in infected root tissues, respectively. Asterisks indicate significant differences in expression (adjusted $P$ value of $\leq 0.01$ and $\mid \log _{2}$ FC $\mid \geq 1$ ). Sequence IDs for each gene in the assembled transcriptome are given in parentheses. 
2012). GRAS family transcription factors NSP1 and NSP2 are also induced by the calcium spike and promote expression of early nodulation genes (Catoira et al. 2000; Oldroyd and Long 2003). Finally, CERBERUS, a putative E3 ubiquitin-protein ligase, is expressed early in nodule formation and appears to be required for proper infection thread development (Yano et al. 2009).

Soybean homologs of many genes described above were differentially expressed in response to reniform nematode infection, including FLOT4, CYCLOPS, NIN, pectate lyase, NSP1, NSP2, and CERBERUS (Fig. 5). Early events in reniform nematode infection appear to share components of the signal transduction pathways involved in perception of rhizobial Nod factors. Indeed, the evolution of these signal transduction pathways may predate both nematode parasitism and rhizobial nodulation, as a recent review suggests that nodulation arose through co-option of genes involved in the ancient mycorrhizal symbiosis (Suzaki et al. 2015).

Once formed, nodules can be costly to maintain. The extent of rhizobial nodulation is therefore limited through the autoregulation of nodulation $(\mathrm{AON})$ program, a long-distance feedback loop in which NIN promotes synthesis of CLE signaling peptides that negatively regulate nodule number (Soyano et al. 2014, Suzaki et al. 2015). Also involved in AON is the o-arabinosyl transferase, RDN1, which adds arabinose to CLE peptides (Kassaw et al. 2015).

Infection by reniform nematode was associated with induction of both NIN and RDN1, as well as up-regulation of five CLE peptides and down-regulation of one CLE peptide (Fig. 5). All CLE peptides were of plant origin and had been previously annotated in the soybean reference genome. Two CLE receptors, homologs of CALVATA1 and ACR4, were also down-regulated (Fig. 6).

This is not the first evidence for a role of CLE peptides in nematode parasitism: previous studies have documented the production of CLE peptide mimics by CN, RKN, and RN (Bakhetia et al. 2007; Guo et al. 2015; Patel et al. 2008; Wang et al. 2005; Wubben et al. 2015). HgSYV46 was the first nematode-derived CLE to be identified from the secretions of the soybean $\mathrm{CN}$ Heterodera glycines (Wang et al. 2005). Its role and that of other CLE mimics was subsequently established through RNAi and receptor knockout studies (Bakhetia et al. 2007; Guo et al. 2015; Patel et al. 2008). RKNs secrete the CLE-like peptide 16D10, and its RNAi silencing causes lower RKN infection (Huang et al. 2006a; Huang et al. 2006b). Recently, the presence of at least three CLE-motif genes has been demonstrated in the dorsal esophageal gland cell of sedentary reniform nematode females (Wubben et al. 2015). The present work suggests that the

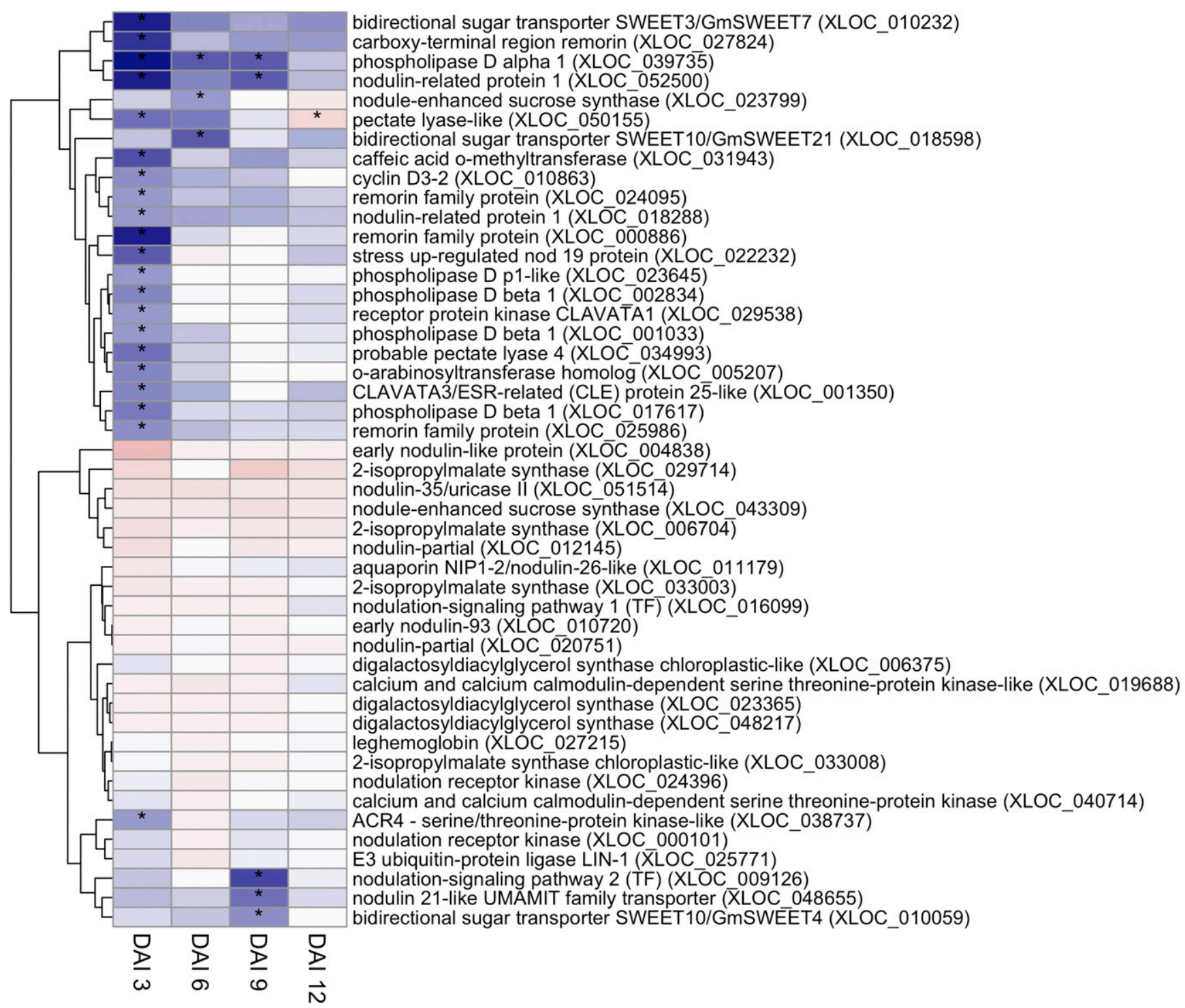

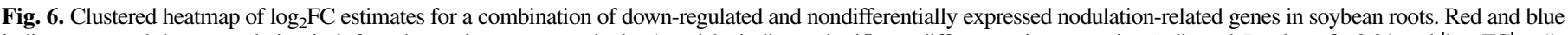

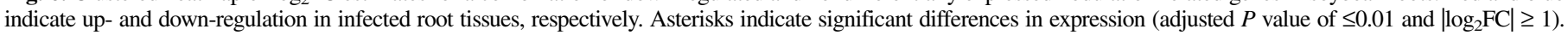

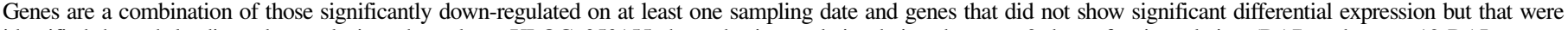
identified through leading-edge analysis or homology. XLOC_050155 showed mix regulation being down on 3 days after inoculation (DAI) and up on 12 DAI. 
plant's own CLE peptides are also involved in the response to RN parasitism.

Other nodulation-related genes. Multiple transporter genes whose expression changed in response to reniform nematode also had documented roles nodulation: three nodulin 26-like intrinsic proteins (NIPs, a family of aquaporins), two vacuolar iron transporters, a nodule-specific zinc transporter and numerous sugar transporters (Fig. 5). Eight of these sugar transporters belonged to the SWEET (sugars will eventually be exported transporters) family of bidirectional sugar uniporters. The first SWEET gene to be identified was a nodulin from Medicago truncatula (MtN3), but SWEETs are known to function in a variety of processes, including phloem loading, nectar secretion, pollen nutrition, and seed filling (Eom et al. 2015; Gamas et al. 1996). Their up-regulation by bacterial and fungal pathogens is thought to promote the release of sugars into the apoplast during early infection stages (Chen et al. 2010).

In addition to SWEET sugar transporters, homologs of the sucrose-proton symporters SUT4 and SUC2 were also up-regulated. Both genes have previously been implicated in phloem loading and unloading (Truernit and Sauer 1995; Weise et al. 2000), and their expression has been documented in nodules and nodule-associated phloem (Complainville et al. 2003; Flemetakis et al. 2003). AtSUC2 expression has also been observed in syncytia induced by the sugar beet cyst nematode, Heterodera schachtii (Juergensen et al. 2003).

The construction of nodules and syncytia necessitates significant changes to cellular membrane systems. In nodules, these changes involve root hair curling, infection thread formation, and production of a plant-derived peribacteroid membrane (Ferguson et al. 2010). In reniform nematode feeding sites, syncytial cells disassemble their central vacuoles, expand the endoplasmic reticulum membrane system, and increase the number of membrane-bound organelles (Agudelo et al. 2005; Rebois et al. 1975). Multiple genes involved in lipid signaling, membrane trafficking, and membrane organization are up-regulated during both biotic interactions.

Four Sec14-like phosphatidylinositol transfer proteins with the GO term nodulation (GO:0009877) were up-regulated in infected roots (Fig. 5). Sec14-like proteins coordinate lipid signaling with membrane trafficking and facilitate the nonenzymatic transfer of phostphatidylinositols and phosphatidylcholine monomers between membrane bilayers (Ghosh and Bankaitis 2011). Sec14-nodulins were first identified in L. japonicus nodules and have been shown to influence polar membrane trafficking and root hair development in Arabidopsis thaliana (Ghosh et al. 2015). Two up-regulated soybean Sec14-like genes contained a GOLD (Golgi dynamics) domain. In Arabidopsis, such genes are termed patellins and are believed to function in vesicle and membrane trafficking, including cell plate formation during cytokinesis (Peiro et al. 2014; Peterman et al. 2004).

A large number of remorins were also differentially expressed in infected roots: nine up-regulated and four down-regulated (Figs. 5 and 6). While their functions are not fully understood, remorins appear to be associated almost exclusively with plasma membrane lipid rafts; several members of the family are strongly induced during nodulation in $M$. truncatula and L. japonicus (Lefebvre et al. 2010). One nodulation-related remorin is thought to function as a scaffolding protein, mediating spatial relationships among the core Nod factor receptor-like kinases NFP, LYK3, and DMI2 in M. truncatula.

Cell cycle and endoreduplication. During rhizobial infection, host cells undergo several rounds of endoreduplication, i.e., replication of the genome without mitosis or cytokinesis, leading to increased nuclear size (Maroti and Kondorosi 2014). The mitotic inhibitor CCS52 is required for this process. It activates the APC ubiquitin protein ligase that degrades mitotic cyclins, blocking the mitotic cell cycle and promoting endoreduplication (Engler and Gheysen 2013; Vinardell et al. 2003).

Reniform nematode infected roots showed up-regulation of two CCS52B homologs (FIZZY-RELATED 3) at 12 DAI (Fig. 5). At 3 DAI, a CCS52A homolog was up-regulated with an FDR-adjusted $P$ value of $\leq 0.01$, although it did not meet our $\log _{2} \mathrm{FC} \geq 1$ cutoff; another CCS52A homolog was up-regulated with an FDR adjusted $P$ value between 0.01 and 0.05 . Also up-regulated at 3 DAI was the transcription factor E2Fa, which is required for endoreduplication (Engler and Gheysen 2013; Vinardell et al. 2003) and whose expression in the Arabidopsis pericycle controls lateral root initiation (Benkova and Bielach 2010).

The up-regulation of endoreduplication genes, enrichment of multiple DNA replication-related gene sets, and the increase in nuclear size previously observed in syncytial cells is consistent with endoreduplication in reniform nematode syncytia. This finding comports with studies of RKN and $\mathrm{CN}$, both of whose feeding structures exhibit increased nuclear size, primarily due to endoreduplication (Edgar et al. 2014). Endoreduplication appears to be vital for successful RKN and $\mathrm{CN}$ feeding site formation, as a knockdown of CCS52 delays feeding site development and decreases reproduction for both nematodes (Vieira et al. 2013).

Genes associated with nitrogen fixation. While similarities in gene expression between nodulation and reniform nematode parasitism may reflect common developmental mechanisms, extensive nodule-related gene expression in parasitized roots may also be a byproduct of nematode interference with nodulation signaling pathways. Some up-regulated nodulation-related genes may be "brought along for the ride" when transcription factors such as CYCLOPS, NIN, NSP1, and NSP2 are induced early in reniform nematode parasitism. Evidence for this hypothesis is provided by the induction of nitrogen fixation genes that have no obvious role in nematode parasitism. A case in point is the expression of three leghemoglobin genes up-regulated from 8.3 -fold to 11.5 -fold at 3 DAI. Leghemoglobins bind oxygen to protect nitrogenase and to manage the movement of oxygen for bacterial respiration (Ott et al. 2005). They have no documented function outside of nitrogen-fixing root nodules, and it is unclear what role they would play in the absence of nitrogenase or rhizobia.

Several lines of evidence suggest that rhizobial contamination was not responsible for changes in gene expression reported here. Surface-sterilized soybean seeds were produced in our lab, free from rhizobial inoculum, and soil was pasteurized prior to seedling transplant. Reniform nematode inoculum was prepared from a field that had been under a continuous nonlegume corn and cotton rotation for many years. Careful visual inspection and microscopy revealed no evidence of nodules or nodule primordia on any sample throughout an 18-day time course (Supplementary File S8). The very small percentage of Illumina reads that could be aligned to rhizobial genomes did not differ in magnitude from the percentage that could be aligned to genomes from $E$. coli and a variety of eukaryotic model organisms (Supplementary File S9). In no case did the small percentage of rhizobial-mappable reads differ between inoculated and control root samples. While some microbial RNA is inevitably sequenced in plant tissue transcriptomes, we found no evidence to suggest there was significant rhizobial contamination.

Conclusion. Our understanding of reniform nematode biology and feeding site formation is limited compared with that of other sedentary endoparasitic nematodes such as RKN and CN. Nonetheless, the overall patterns of gene expression reported here share features with transcriptomes from better-studied nematode-host interactions. Many genes affected by reniform nematode infection also share similarities with mutualistic belowground symbioses such as nodulation and mycorrhization, and it has been suggested that multiple belowground symbionts and parasites manipulate aspects of the lateral root organogenesis program to form symbiotic structures (Mathesius 2003). If an ultimate goal is nematode management, then the similarities among diverse belowground processes may be less important than their specific differences. A comparative approach to the transcriptomic changes induced by lateral root organogenesis, mycorrhization, nodule formation, and nematode parasitism will allow us to pinpoint how one organism induces formation of a beneficial nodule while another induces formation of a harmful feeding site. Breeding and genetic engineering efforts can be focused on disrupting molecular events that 
are unique to nematode infection while avoiding pathways that function in normal organogenesis and beneficial symbioses.

\section{ACKNOWLEDGMENTS}

Funding for this work was provided by the South Carolina Soybean Board and Cotton Incorporated (Project 16-341SC).

\section{LITERATURE CITED}

Agudelo, P., Robbins, R. T., Kim, K. S., and Stewart, J. M. 2005. Histological changes in Gossypium hirsutum associated with reduced reproduction of Rotylenchulus reniformis. J. Nematol. 37:185-189.

Albrecht, C., Geurts, R., and Bisseling, T. 1999. Legume nodulation and mycorrhizae formation; Two extremes in host specificity meet. EMBO J. 18:281-288.

Anders, S., Pyl, P. T., and Huber, W. 2015. HTSeq-A python framework to work with high-throughput sequencing data. Bioinformatics 31:166-169.

Bakhetia, M., Urwin, P. E., and Atkinson, H. J. 2007. qPCR analysis and RNAi define pharyngeal gland cell-expressed genes of Heterodera glycines required for initial interactions with the host. Mol. Plant-Microbe Interact. 20: 306-312

Bellafiore, S., Shen, Z., Rosso, M., Abad, P., Shih, P., and Briggs, S. P. 2008. Direct identification of the Meloidogyne incognita secretome reveals proteins with host cell reprogramming potential. PLoS Pathog. 4:e1000192.

Benkova, E., and Bielach, A. 2010. Lateral root organogenesis-From cell to organ. Curr. Opin. Plant Biol. 13:677-683.

Bolger, A. M., Lohse, M., and Usadel, B. 2014. Trimmomatic: A flexible trimmer for Illumina sequence data. Bioinformatics 30:2114-2120.

Bybd, D., Kirkpatrick, T., and Barker, K. 1983. An improved technique for clearing and staining plant-tissues for detection of nematodes. J. Nematol. 15:142-143.

Cabrera, J., Díaz-Manzano, F. E., Fenoll, C., and Escobar, C. 2015. Chapter seven-Developmental pathways mediated by hormones in nematode feeding sites. Adv. Bot. Res. 73:167-188.

Catoira, R., Galera, C., de Billy, F., Penmetsa, R., Journet, E., Maillet, F., Rosenberg, C., Cook, D., Gough, C., and Denarie, J. 2000. Four genes of Medicago truncatula controlling components of a nod factor transduction pathway. Plant Cell 12:1647-1665.

Chen, L., Hou, B., Lalonde, S., Takanaga, H., Hartung, M. L., Qu, X., Guo, W., Kim, J., Underwood, W., Chaudhuri, B., Chermak, D., Antony, G., White, F. F., Somerville, S. C., Mudgett, M. B., and Frommer, W. B. 2010. Sugar transporters for intercellular exchange and nutrition of pathogens. Nature 468:527-532.

Complainville, A., Brocard, L., Roberts, I., Dax, E., Sever, N., Sauer, N., Kondorosi, A., Wolf, S., Oparka, K., and Crespi, M. 2003. Nodule initiation involves the creation of a new symplasmic field in specific root cells of Medicago species. Plant Cell 15:2778-2791.

Conesa, A., Gotz, S., Garcia-Gomez, J., Terol, J., Talon, M., and Robles, M. 2005. Blast2GO: A universal tool for annotation, visualization and analysis in functional genomics research. Bioinformatics 21:3674-3676.

de Almeida Engler, J., Vieira, P., Rodiuc, N., Grossi de Sa, M. F., and Engler, G. 2015. Chapter four-The plant cell cycle machinery: Usurped and modulated by plant-parasitic nematodes. Adv. Bot. Res. 73:91-118.

Denance, N., Szurek, B., and Noel, L. D. 2014. Emerging functions of nodulin-like proteins in non-nodulating plant species. Plant Cell Physiol. $55: 469-474$

Desbrosses, G. J., and Stougaard, J. 2011. Root nodulation: A paradigm for how plant-microbe symbiosis influences host developmental pathways. Cell Host Microbe 10:348-358.

Edgar, B. A., Zielke, N., and Gutierrez, C. 2014. Endocycles: A recurrent evolutionary innovation for post-mitotic cell growth. Nat. Rev. Mol. Cell Biol. 15:197-210.

Endre, G., Kereszt, A., Kevei, Z., Mihacea, S., Kalo, P., and Kiss, G. 2002. A receptor kinase gene regulating symbiotic nodule development. Nature 417: 962-966.

Engler, J. A., and Gheysen, G. 2013. Nematode-induced endoreduplication in plant host cells: Why and how? Mol. Plant-Microbe Interact. 26:17-24.

Eom, J., Chen, L., Sosso, D., Julius, B. T., Lin, I. W., Qu, X., Braun, D. M., and Frommer, W. B. 2015. SWEETs, transporters for intracellular and intercellular sugar translocation. Curr. Opin. Plant Biol. 25:53-62.

Eves-Van den Akker, S., Lilley, C. J., Yusup, H. B., Jones, J. T., and Urwin, P. E. 2016. Functional C-TERMINALLY ENCODED PEPTIDE (CEP) plant hormone domains evolved de novo in the plant parasite Rotylenchulus reniformis. Mol. Plant Pathol. 17:1265-1275.

Favery, B., Complainville, A., Vinardell, J., Lecomte, P., Vaubert, D., Mergaert, P., Kondorosi, A., Kondorosi, E., Crespi, M., and Abad, P. 2002. The endosymbiosis-induced genes ENOD40 and CCS52a are involved in endoparasitic-nematode interactions in Medicago truncatula. Mol. PlantMicrobe Interact. 15:1008-1013.
Ferguson, B. J., Indrasumunar, A., Hayashi, S., Lin, M., Lin, Y., Reid, D. E., and Gresshoff, P. M. 2010. Molecular analysis of legume nodule development and autoregulation. J. Integr. Plant Biol. 52:61-76.

Flemetakis, E., Dimou, M., Cotzur, D., Efrose, R. C., Aivalakis, G., Colebatch, G., Udvardi, M., and Katinakis, P. 2003. A sucrose transporter, LjSUT4, is upregulated during lotus japonicus nodule development. J. Exp. Bot. 54:1789-1791.

$\mathrm{Fu}, \mathrm{Q} ., \mathrm{Li}, \mathrm{S}$., and Yu, D. 2010. Identification of an Arabidopsis nodulinrelated protein in heat stress. Mol. Cells 29:77-84.

Gamas, P., de Carvalho-Niebel, F., Lescure, N., and Cullimore, J. 1996. Use of a subtractive hybridization approach to identify new Medicago truncatula genes induced during root nodule development. Mol. Plant-Microbe Interact. 9:233-242.

Ghosh, R., and Bankaitis, V. A. 2011. Phosphatidylinositol transfer proteins: Negotiating the regulatory interface between lipid metabolism and lipid signaling in diverse cellular processes. Biofactors 37:290-308.

Ghosh, R., de Campos, M. K. F., Huang, J., Huh, S. K., Orlowski, A., Yang, Y., Tripathi, A., Nile, A., Lee, H., Dynowski, M., Schaefer, H., Rog, T., Lete, M. G., Ahyayauch, H., Alonso, A., Vattulainen, I., Igumenova, T. I., Schaaf, G., and Bankaitis, V. A. 2015. Sec14-nodulin proteins and the patterning of phosphoinositide landmarks for developmental control of membrane morphogenesis. Mol. Biol. Cell 26:1764-1781.

Guo, X., Chronis, D., De La Torre, C. M., Smeda, J., Wang, X., and Mitchum, M. G. 2015. Enhanced resistance to soybean cyst nematode Heterodera glycines in transgenic soybean by silencing putative CLE receptors. Plant Biotechnol. J. 13:801-810.

Heald, C., and Robinson, A. 1990. Survey of current distribution of Rotylenchulus reniformis in the United States. J. Nematol. 22:695-699.

Huang, G., Allen, R., Davis, E. L., Baum, T. J., and Hussey, R. S. 2006a. Engineering broad root-knot resistance in transgenic plants by RNAi silencing of a conserved and essential root-knot nematode parasitism gene. Proc. Natl. Acad. Sci. USA 103:14302-14306.

Huang, G., Dong, R., Allen, R., Davis, E., Baum, T., and Hussey, R. 2006b. A root-knot nematode secretory peptide functions as a ligand for a plant transcription factor. Mol. Plant-Microbe Interact. 19:463-470.

Huang, P., Catinot, J., and Zimmerli, L. 2016. Ethylene response factors in Arabidopsis immunity. J. Exp. Bot. 67:1231-1241.

Hutangura, P., Mathesius, U., Jones, M. G. K., and Rolfe, B. G. 1999. Auxin induction is a trigger for root gall formation caused by root-knot nematodes in white clover and is associated with the activation of the flavonoid pathway. Aust. J. Plant Physiol. 26:221-231.

Langmead, B., and Salzberg, S. 2012. Fast gapped-read alignment with Bowtie 2. Nat. Methods 9:357-359.

Jaouannet, M., Magliano, M., Arguel, M. J., Gourgues, M., Evangelisti, E., Abad, P., and Rosso, M. N. 2013. The root-knot nematode calreticulin mi-CRT is a key effector in plant defense suppression. Mol. Plant-Microbe Interact. 26:97-105.

Jenkins, W. R. 1964. A rapid centrifugal-flotation technique for separating nematodes from soil. Plant Dis Rep. 48:692.

Jones, M. G. K., and Dropkin, V. H. 1975. Cellular alterations induced in soybean roots by three endoparasitic nematodes. Physiol. Plant Pathol. 5:119-124.

Juergensen, K., Scholz-Starke, J., Sauer, N., Hess, P., van Bel, A., and Grundler, F. 2003. The companion cell-specific Arabidopsis disaccharide carrier AtSUC2 is expressed in nematode-induced syncytia. Plant Physiol. 131:61-69.

Kassaw, T., Bridges, W., Jr., and Frugoli, J. 2015. Multiple autoregulation of nodulation (AON) signals identified through split root analysis of Medicago truncatula sunn and rdn1 mutants. Plants-Basel 4:209-224.

Kennedy, M., Niblack, T., and Krishnan, H. 1999. Infection by Heterodera glycines elevates isoflavonoid production and influences soybean nodulation. J. Nematol. 31:341-347.

Lefebvre, B., Timmers, T., Mbengue, M., Moreau, S., Herve, C., Toth, K., Bittencourt-Silvestre, J., Klaus, D., Deslandes, L., Godiard, L., Murray, J. D., Udvardi, M. K., Raffaele, S., Mongrand, S., Cullimore, J., Gamas, P., Niebel, A., and Ott, T. 2010. A remorin protein interacts with symbiotic receptors and regulates bacterial infection. Proc. Natl. Acad. Sci. USA 107:2343-2348.

Li, R., Rashotte, A. M., Singh, N. K., Lawrence, K. S., Weaver, D. B., and Locy, R. D. 2015. Transcriptome analysis of cotton (Gossypium hirsutum L.) genotypes that are susceptible, resistant, and hypersensitive to reniform nematode (Rotylenchulus reniformis). PLoS One 10:e143261.

Liu, C., and Murray, J. D. 2016. The role of flavonoids in nodulation hostrange specificity: An update. Plants-Basel 5:33.

Lohar, D., and Bird, D. 2003. Lotus japonicus: A new model to study rootparasitic nematodes. Plant Cell Physiol. 44:1176-84.

Lohar, D., Schaff, J., Laskey, J., Kieber, J., Bilyeu, K., and Bird, D. 2004. Cytokinins play opposite roles in lateral root formation, and nematode and rhizobial symbioses. Plant J. 38:203-214.

Love, M. I., Huber, W., and Anders, S. 2014. Moderated estimation of fold change and dispersion for RNA-seq data with DESeq2. Genome Biol. 15:550.

Madsen, E., Madsen, L., Radutoiu, S., Olbryt, M., Rakwalska, M., Szczyglowski, K., Sato, S., Kaneko, T., Tabata, S., Sandal, N., and Stougaard, J. 2003. A receptor kinase gene of the LysM type is involved in legume perception of rhizobial signals. Nature 425:637-640. 
Maroti, G., and Kondorosi, E. 2014. Nitrogen-fixing rhizobium-legume symbiosis: Are polyploidy and host peptide-governed symbiont differentiation general principles of endosymbiosis? Front. Microbiol. 5:326.

Mathesius, U. 2003. Conservation and divergence of signaling pathways between roots and soil microbes-The rhizobium-legume symbiosis compared to the development of lateral roots, mycorrhizal interactions and nematodeinduced galls. Plant Soil 255:105-119.

McCarter, J. P., Mitreva, M. D., Martin, J., Dante, M., Wylie, T., Rao, U., Pape, D., Bowers, Y., Theising, B., Murphy, C. V., Kloek, A. P., Chiapelli, B. J., Clifton, S. W., Bird, D. M., and Waterston, R. H. 2003. Analysis and functional classification of transcripts from the nematode Meloidogyne incognita. Genome Biol. 4:R26.

Mitra, R., Shaw, S., and Long, S. 2004. Six nonnodulating plant mutants defective for nod factor-induced transcriptional changes associated with the legume-rhizobia symbiosis. Proc. Natl. Acad. Sci. USA 101:10217-10222.

Oldroyd, G., and Long, S. 2003. Identification and characterization of nodulation-signaling pathway 2, a gene of Medicago truncatula involved in nod factor signaling. Plant Physiol. 131:1027-1032.

Ott, T., van Dongen, J., Gunther, C., Krusell, L., Desbrosses, G., Vigeolas, H., Bock, V., Czechowski, T., Geigenberger, P., and Udvardi, M. 2005. Symbiotic leghemoglobins are crucial for nitrogen fixation in legume root nodules but not for general plant growth and development. Curr. Biol. 15:531-535.

Patel, N., Hamamouch, N., Li, C., Hussey, R., Mitchum, M., Baum, T., Wang, X., and Davis, E. L. 2008. Similarity and functional analyses of expressed parasitism genes in Heterodera schachtii and Heterodera glycines. J. Nematol. 40:299-310.

Peiro, A., Cristina Izquierdo-Garcia, A., Angel Sanchez-Navarro, J., Pallas, V., Miguel Mulet, J., and Aparicio, F. 2014. Patellins 3 and 6, two members of the plant patellin family, interact with the movement protein of alfalfa mosaic virus and interfere with viral movement. Mol. Plant Pathol. 15:881-891.

Peterman, T., Ohol, Y., McReynolds, L., and Luna, E. 2004. Patellin1, a novel Sec14-like protein, localizes to the cell plate and binds phosphoinositides. Plant Physiol. 136:3080-3094.

Quentin, M., Abad, P., and Favery, B. 2013. Plant parasitic nematode effectors target host defense and nuclear functions to establish feeding cells. Front. Plant Sci. 4:53.

Rebois, R. V. 1980. Ultrastructure of a feeding peg and tube associated with Rotylenchulus reniformis in cotton. Nematologica 26:396-405.

Rebois, R. V., Madden, P. A., and Eldridge, B. J. 1975. Some ultrastructural changes induced in resistant and susceptible soybean roots following infection by Rotylenchulus reniformis. J. Nematol. 7:122-139.

Reddy, P., Aggarwal, R., Ramos, M., Ladha, J., Brar, D., and Kouchi, H. 1999. Widespread occurrence of the homologues of the early nodulin (ENOD) genes in Oryza species and related grasses. Biochem. Biophys. Res. Commun. 258:148-154

Robinson, A. F., Inserra, R. N., Caswell-Chen, E. P., Vovlas, N., and Troccoli, A. 1997. Rotylenchulus species: Identification, distribution, host ranges, and crop plant resistance. Nematropica 27:127-180.

Robinson, A. F. 2007. Reniform in US cotton: When, where, why, and some remedies. Annu. Rev. Phytopathol. 45:263-288.

Schmutz, J., Cannon, S. B., Schlueter, J., Ma, J., Mitros, T., Nelson, W., Hyten, D. L., Song, Q., Thelen, J. J., Cheng, J., Xu, D., Hellsten, U., May, G. D., Yu, Y., Sakurai, T., Umezawa, T., Bhattacharyya, M. K., Sandhu, D., Valliyodan, B., Lindquist, E., Peto, M., Grant, D., Shu, S., Goodstein, D., Barry, K., Futrell-Griggs, M., Abernathy, B., Du, J., Tian, Z., Zhu, L., Gill, N., Joshi, T., Libault, M., Sethuraman, A., Zhang, X., Shinozaki, K., Nguyen, H. T., Wing, R. A., Cregan, P., Specht, J., Grimwood, J., Rokhsar, D., Stacey, G., Shoemaker, R. C., and Jackson, S. A. 2010. Genome sequence of the palaeopolyploid soybean. Nature 463:178-183.

Singh, S., Katzer, K., Lambert, J., Cerri, M., and Parniske, M. 2014. CYCLOPS, A DNA-binding transcriptional activator, orchestrates symbiotic root nodule development. Cell Host Microbe 15:139-152.

Smeds, L., and Kunstner, A. 2011. CONDETRI-A content dependent read trimmer for Illumina data. PLoS One 6:e26314.

Soyano, T., Hirakawa, H., Sato, S., Hayashi, M., and Kawaguchi, M. 2014. NODULE INCEPTION creates a long-distance negative feedback loop involved in homeostatic regulation of nodule organ production. Proc. Natl. Acad. Sci. USA 111:14607-14612.
Stracke, S., Kistner, C., Yoshida, S., Mulder, L., Sato, S., Kaneko, T., Tabata, S., Sandal, N., Stougaard, J., Szczyglowski, K., and Parniske, M. 2002. A plant receptor-like kinase required for both bacterial and fungal symbiosis. Nature 417:959-962.

Subramanian, A., Tamayo, P., Mootha, V., Mukherjee, S., Ebert, B., Gillette, M., Paulovich, A., Pomeroy, S., Golub, T., Lander, E., and Mesirov, J. 2005. Gene set enrichment analysis: A knowledge-based approach for interpreting genomewide expression profiles. Proc. Natl. Acad. Sci. USA 102:15545-15550.

Suzaki, T., Yoro, E., and Kawaguchi, M. 2015. Leguminous plants: Inventors of root nodules to accommodate symbiotic bacteria. Int. Rev. Cell Mol. Biol. 316:111-158.

Trapnell, C., Roberts, A., Goff, L., Pertea, G., Kim, D., Kelley, D. R., Pimentel, H., Salzberg, S. L., Rinn, J. L., and Pachter, L. 2012. Differential gene and transcript expression analysis of RNA-seq experiments with TopHat and Cufflinks. Nat. Protoc. 7:562-578.

Truernit, E., and Sauer, N. 1995. The promoter of the Arabidopsis thaliana SUC2 sucrose-H+ symporter gene directs expression of beta-glucuronidase to the phloem-Evidence for phloem loading and unloading by SUC2. Planta 196:564-570.

Verma, D., Fortin, M., Stanley, J., Mauro, V., Purohit, S., and Morrison, N. 1986. Nodulins and nodulin genes of Glycine max-A perspective. Plant Mol. Biol. 7:51-61.

Vieira, P., Kyndt, T., Gheysen, G., and de Almeida Engler, J. 2013. An insight into critical endocycle genes for plant-parasitic nematode feeding sites establishment. Plant Signal. Behav. 8:e24223.

Vieira-de-Mello, G. S., dos Santos, P. B., Soares-Cavalcanti, N. M., and Benko-Iseppon, A. M. 2011. Identification and expression of early nodulin in sugarcane transcriptome revealed by in silico analysis. Lect. Notes Bioinform. 6685:72-85.

Vinardell, J. M., Fedorova, E., Cebolla, A., Kevei, Z., Horvath, G., Kelemen, Z., Tarayre, S., Roudier, F., Mergaert, P., Kondorosi, A., and Kondorosi, E. 2003. Endoreduplication mediated by the anaphase-promoting complex activator CCS52A is required for symbiotic cell differentiation in Medicago truncatula nodules. Plant Cell 15:2093-2105.

Wang, X., Mitchum, M., Gao, B., Li, C., Diab, H., Baum, T., Hussey, R., and Davis, E. 2005. A parasitism gene from a plant-parasitic nematode with function similar to CLAVATA3/ESR (CLE) of Arabidopsis thaliana. Mol. Plant Pathol. 6:187-191.

Wasson, A. P., Ramsay, K., Jones, M. G. K., and Mathesius, U. 2009. Differing requirements for flavonoids during the formation of lateral roots, nodules and root knot nematode galls in Medicago truncatula. New Phytol. 183:167-179.

Weerasinghe, R., Bird, D., and Allen, N. 2005. Root-knot nematodes and bacterial nod factors elicit common signal transduction events in Lotus japonicus. Proc. Natl. Acad. Sci. USA 102:3147-3152.

Weise, A., Barker, L., Kuhn, C., Lalonde, S., Buschmann, H., Frommer, W., and Ward, J. 2000. A new subfamily of sucrose transporters, SUT4, with low affinity/high capacity localized in enucleate sieve elements of plants. Plant Cell 12:1345-1355.

Wieczorek, K. 2015. Chapter three-Cell wall alterations in nematode-infected roots. Adv. Bot. Res. 73:61-90.

Wubben, M. J., Gavilano, L., Baum, T. J., and Davis, E. L. 2015. Sequence and spatiotemporal expression analysis of CLE-motif containing genes from the reniform nematode (Rotylenchulus reniformis Linford \& Oliveira). J. Nematol. 47:159-165.

Xie, F., Murray, J. D., Kim, J., Heckmann, A. B., Edwards, A., Oldroyd, G. E. D., and Downie, A. 2012. Legume pectate lyase required for root infection by rhizobia. Proc. Natl. Acad. Sci. USA 109:633-638.

Yano, K., Shibata, S., Chen, W., Sato, S., Kaneko, T., Jurkiewicz, A., Sandal, N., Banba, M., Imaizumi-Anraku, H., Kojima, T., Ohtomo, R., Szczyglowski, K., Stougaard, J., Tabata, S., Hayashi, M., Kouchi, H., and Umehara, Y. 2009. CERBERUS, a novel U-box protein containing WD-40 repeats, is required for formation of the infection thread and nodule development in the legumerhizobium symbiosis. Plant J. 60:168-80.

Zhao, J. 2015. Phospholipase D and phosphatidic acid in plant defence response: From protein-protein and lipid-protein interactions to hormone signaling. J. Exp. Bot. 66:1721-1736. 